\title{
Structure-Activity Relationship Study of Synthetic Variants Derived from the Highly Potent Human Antimicrobial Peptide hLF(1-11)
}

\author{
Carlo PJM Brouwer ${ }^{1,2,3 *}$, Luca Roscini ${ }^{4}$, Gianluigi Cardinali ${ }^{4,5}$, Laura Corte ${ }^{4}$, Debora Casagrande Pierantoni ${ }^{4}$, \\ Vincent Robert ${ }^{1,3}$, Mahfuzur Rahman ${ }^{2}$ and Mick M Welling ${ }^{6}$
}

${ }^{1}$ Westerdijk, Fungal Biodiversity Institute, Uppsalalaan 8, Utrecht 3584 CT, The Netherlands

${ }^{2}$ CBMR Scientific Inc., Edmonton, Alberta, Canada

${ }^{3}$ BioAware Life Sciences Data Management Software, Rue du Henrifontaine 20, B-4280 Hannut, Belgium

${ }^{4}$ University of Perugia, Department of Pharmaceutical sciences, Borgo 20 Giugno, 74, I-06121 Perugia, Italy

${ }^{5}$ CEMIN Research Centre of Excellence, University of Perugia, Italy

${ }^{6}$ Interventional Molecular Imaging Laboratory, Department of Radiology, Leiden University Medical Center, Leiden, the Netherlands

*Corresponding author: Carlo PJM Brouwer, Westerdijk Fungal Biodiversity Institute, Uppsalalaan 8, Utrecht 3584 CT, Netherlands

Submission: 阱 January 31, 2018; Published: 海 March 13, 2018

\begin{abstract}
Antimicrobial peptides are omnipresent in nature and act as the first line of defence of the host against infectious agents. A synthetic antimicrobial peptide derived from the $N$-terminus of human lactoferrin hLF(1-11) (GRRRRSVQWCA), displays antibacterial as well as antifungal activity in vitro and in vivo. In order to elucidate the mechanism of antimicrobial action of hLF(1-11), we have synthesised several peptides analogues derived from hLF(111) to test their activity against various fungal and bacterial strains. In this way, a general trend on the importance of the order and position of amino acid residues for biological activity against various organisms could be drawn.

In this study, the full Ala-scan has been synthesised (i.e. series of structural variants where a different residue is replaced with an alanine residue); the affinity of the analogue peptide was assessed and compared with that of the original. Additionally, we performed combination therapy with hLF (1-11) peptides and classical antibiotics as this may serve as an alternative approach to improve antimicrobial treatment outcome in drug resistant strains. The biological tests showed a decrease in the activity of the peptide when one out of the first three arginine residues, the tryptophan or the cysteine residue were replaced by alanine. Replacement of the cysteine residue by a serine residue or by a methylated cysteine led to peptides that were significantly less potent than the reference peptide hLF(1-11) . However, the peptide containing a cysteine residue; the disulphide dimer showed the same activity as the monomer. Finally, it was also possible to replace the tryptophan residue by another aromatic residue phenylalanine without any loss of activity. Amidation of the $C$-terminus did not negatively affect the biological activity of the peptide but even increased, while acetylation of the $N$-terminus led to a significant loss of antimicrobial activity. The synthesis of analogues from hLF(1-11) and their use in biological tests revealed the importance of some amino acid residues for antimicrobial activity; that are arginine (position 2), tryptophan (position 9) and cysteine (position 10). Secondly, in combination with classical antibiotics even for the drug resistant species we found synergistic interactions between the peptide and antibiotics in vivo. In conclusion, some amino acid sequences/places of hLF(1-11)are important for the antimicrobial actions and in synergistic processes.
\end{abstract}

Keywords: AMP; Biological activity; Synergism; Fungal infections

\section{Introduction}

The alarming rate of bacterial and fungal resistance induction highlights the clinical need for new source of antimicrobial and antifungal compounds despite remarkable advances has been made in antibiotic and fungal chemotherapy [1,2]. For fungal infections, several systemic antifungal agents have been developed for the treatment of candidiasis, including fluconazole, itraconazole, and amphotericin B. Fluconazole is frequently selected for systemic therapy of candidiasis because it is well tolerated and has excellent oral bioavailability. Common use of conventional antibiotics has resulted in an increasing number of multi-resistant microorganisms which became a permanent threat for immunocompromised patients. During the past years, however, the increasing reports of fluconazole resistant candidiasis (OPEC) and the emergence of outbreaks with OPEC has heightened the need for development of innovative treatments with new antifungal compounds with non cross-resistant novel targets [3-7]. 
Those therapeutic agents are essential for a broad array of diagnosis; increasing patient groups dealing with transplantation, cancer irradiation and drugs, neonates and patients with primary immunodeficiency diseases. Although the immunosuppression can be accomplished by one of several ways (hydrocortisone, cyclosporine etc.) [8], these treatment may induce possible confounding factors and alter both host cell responses and subsequent cytokine synthesis and regulation [9]. Unfortunately, treatment of invasive fungal infections is often hampered by drug toxicity, poor tolerability and strain specificity issues, and additional complications often arise due to the lack of diagnostic tests and to treatment complexities [10].

For medical need, bloodstream candidiasis is the most commonly encountered invasive fungal infection in hospitalized patients (ICU) and the fourth most common cause of hospitalacquired bloodstream infections in the US and in many European medical centers [11-14]. Treatment is often difficult and failure (US) $20-60 \%$ (Candidemia) whereof $6-17 \%$ is persistently. In most cases $30-40 \%$ of these persistently infected patients died. With the advent of highly active antiretroviral therapy (HAART), and the associated decline in HIV patients vulnerable to fungal infection, commercial interest in antifungal development has wanted, with only five products in Phase I/ II development. As such, there are limited opportunities for companies with aging portfolios to in license novel products [15]. Rare mycoses constitute between 13$15 \%$ of all invasive fungal infections. The launch of a broad-spectrum therapy that is active against a range of mycoses would increase uptake in hospital environment [15]. There are few data to suggest that secondary (acquired) antifungal resistance is prominent or increasing in the US or Europe among bloodstream infections due to C. albicans $[12,16,17]$. There remains a high level of clinical unmet within the market, particularly in terms of high mortality rates associated with invasive infections despite treatment. These factors will drive physicians to continue switching to higher priced novel products $[15,18]$. Second, there is a need for an antifungal with broad spectrum, low potential for development of resistance and favorable side effect profile $[19,20]$. Third, availability of a variety of formulation is a distinct advantage. This enables physicians to switch from an IV formulation to an oral product for out-patient treatment, thereby reducing patient time in hospital and cutting overall treatment cost.

For some decades, many cationic peptides have been discovered and these antimicrobial peptides (AMPs) display a broad spectrum of antimicrobial activities, including antimicrobial action directed against bacteria, eukaryotic parasites, viruses, and fungi [21]. AMPs are part of the innate immune system of all kind of organisms ranging from bacteria to humans and they represent the first line of defense against microorganisms (e.g. bacteria, viruses and fungi). Generally, AMPs are short cationic peptides with amphipathic properties which allow them to interact with and pass through membranes. Cationic antimicrobial peptides can be broadly categorized on base of their action
A. Action of AMPs on outer membrane, AMPs interact with highly negatively charged outer membrane [21].

B. Action of AMPs on cytoplasmic membranes, such as cell lysis, channel- formation, membrane integrity and direct killing of the microorganism by attacking internal targets.

C. Roles in immunity, AMPs not only directly kill bacteria, they also have profound effects on the host system defense [22-24]. Because of their net positive charge, they have affinity for phospholipids double layers and their bactericidal affect is thought to be due to the formation of pores in the cytoplasmic membrane of susceptible pathogens [21]. Most important is that mammalian cells carry cholesterol in their membranes neutralizing the charged groups resulting in neutral net charge so they are at normal concentrations less affected by cationic peptides; rigidity in elasticity which inhibits pore-formation [25]. As a result, at physiological concentrations most AMPs poorly binds and disrupts host cells [26]. Due to this non-specific mode of action AMPs remain effective against strains of antibiotic resistant pathogens, and they rapidly emerged as alternative candidates for new kind of antibiotics against which the microorganisms cannot easily develop resistance.

Human lactoferrin, a $80 \mathrm{kDa}$ iron-binding protein, is a major component of the non-specific defense of mucosal surfaces and neutrophils [27]. It has been demonstrated that hLF(1-11), an eleven amino acid peptide corresponding to the $\mathrm{N}$-terminus of human lactoferrin, is more potential than the whole LF protein against a variety of bacteria and yeasts in vitro and in mice, rats and rabbits [28,29]. As a reason of its human origin, $\operatorname{hLF}(1-11)$ appears as a promising candidate that would resist to proteolytic degradation [30,31]. Indeed, its use in a controlled patient studies has shown effective biological activity and it is well tolerated without side effects [32,33].

However, the mode of action of this peptide is still not clear. In order to get more insight into its mechanism of action, for this purpose we have synthesized various peptides derived with altering and replacing the amino acid sequence and tested them for biological activity against various gram-positive bacteria, gram negative bacteria, and fungi. Furthermore, we tested the peptides in combination with several antimicrobial (fungi \& bacteria) agents to explore possible synergistic effects of combinational therapy.

To build up the research, we looked for substitutions of amino acids to enable functionalization of the peptide without loss of biological activity;

A. Function relationship position and origin amino acids,

B. Substitutions to enable modifications for biological evaluation, and

C. Effect of synergy on antimicrobial treatment.

(1) To find a clear understanding of structures responsible for peptide biology in this study we focus on the exploration of 
secondary structures identified by systematic scanning of each residue in the peptide sequence by replacement them one-by-one with other amino acids. Here, alanine scans will be performed to study the importance of side chains and conformation on the biological activity of the peptide (reference). A general feature of many anti-microbial peptides is the presence of domains containing multiple arginines and lysins. Combined with the fact that arginines (Arg) in proteins and peptides can be deiminated, rendering citrullin (Cit) at sides of infections led to the hypothesis that Arg-Cit metabolism may be a factor that accounts for hLF(111)'s higher in vivo efficacy compared with in vitro [34]. To test this hypothesis, combinations of Arg-Cit substituted hLF(1-11) peptides will be synthesized and tested for in-vitro enhanced efficacy. $h L F(1-11)$ seems to bind covalently to serum proteins (albumin), most likely through intermolecular cystine bonding through hLF's Cys and S-methyl-Cys [35]. hLF has been proposed as an alternative compound with potentially improved bioavailability. In order to understand the working mechanism of hLF(1-11) we develop various peptides, such as functionalized Threonine variant (GRRRRSVQWCT*), Fluorescently labeled peptide, Biotin labeled peptide, Biotin + photoactivatable double labeled peptide, Retroin verso variant, S-methylcysteine variant , and Arginine/citrullinsubstituted peptides.

(2) As a next step the analogs can be tested for antimicrobial activity. If all compounds have similar microbicidal activity then it may be assumed that interactions with proteins are not important. If only hLF(1-11) shows activity then it is likely that besides a direct effect on membrane integrity also additional specific peptide protein interactions are important [36-38]. Combination therapy has been suggested as a possible approach to improve treatment outcome [39-42]. Therefore, development of first eleven amino-acids of human Lactoferrin derived peptide (hLF1-11) as a compound for combating fluconazole resistant $C$. albicans is narrow an indication. Their unique mechanism of action and the excellent safety profile in humans [32] make hLF(1-11) appealing candidate for simultaneous or sequential use in Candida infections where the failure rate of primary therapy averages. As the results of our preliminary pilot experiments with combinations of hLF(1-11) peptide and fluconazole in mice infected with fluconazole-resistant C. albicans were promising, in this study we will investigate such combinations to establish the possible synergistic effects of (various doses) the peptide and fluconazole (i.p.; $200 \mu \mathrm{g} / \mathrm{kg}$ ). As read-outs we determine the number of surviving Candida in the kidneys microbiologically and the changes in Candida morphology in kidney sections [43].

(3) Furthermore, we will determine the effects of combinations of the peptide and the various antifungal against an infection with fluconazole-sensitive $C$. albicans and a non-albicans Candida, e.g. C. glabrata. Additionally, we study the synergistic activities (combination therapy) of hLF(1-11) with two antifungals against different resistant and sensitive Candida species. However, this manuscript is mainly focused on antifungal activity of the peptide, also we examined the antimicrobial activity as well on different bacterial strains this in order to obtain more insight in the broad activity of the hLF(1-11) peptides.

\section{Materials and Methods}

\section{Chemical and reagents}

Fmoc-protected amino acids were purchased from GL biochem Ltd (Shangai, China), except $N$ Fmoc-S- Me-OH which was synthesized according to standard procedures. Peptide grade solvents for synthesis were purchased from Biosolve (The Netherlands). TFA was purchased from Biosolve (The Netherlands). TentaGel S RAM and TentaGel S PHB resins were purchased from Rapp polymere GmBH (Tübingen, Germany). Benzotriazol-1yloxytris (dimethylamino) phosphonium hexafluorophosphate (BOP) was purchased from GL Biochem Ltd (Shangai, China). DiPEA and acetic anhydride were purchased from Acros Organics (Belgium).

\section{Boc-Cys-OH}

Cysteine (GL biochem Ltd, Shangai, China) (6.2g, 51.0mmol, $1.02 \mathrm{eq}$ ) was added to $100 \mathrm{~mL}$ of water/dioxane $1: 1 \mathrm{v} / \mathrm{v} .55 \mathrm{~mL}$ of $2 \mathrm{M} \mathrm{NaOH}$ was added to the previous solution, followed by Boc anhydride (GL biochem Ltd, Shangai, China) (10.9g, 50.0mmol, $1.00 \mathrm{eq}$ ) and the reaction mixture was stirred overnight at room temperature. The dioxane was evaporated and the basic aqueous phase was extracted with diethyl ether. The aqueous was acidified to $\mathrm{pH} 2$ by the addition of $1 \mathrm{M}$ potassium hydrogen sulfate and the product was extracted with ethyl acetate. The organic layer was washed once with $1 \mathrm{M}$ potassium hydrogen sulfate, 3 times with brine, dried over sodium sulfate and the solvent was evaporated. We obtained $9.0 \mathrm{~g}(40.7 \mathrm{mmol}, 80 \%)$ of colorless oil that was used without further purification.

\section{Boc Cys(Me) OH}

Under nitrogen, Boc-Cys-OH (8.3g, 37.5mmol, 1.0eq) was dissolved in $70 \mathrm{~mL}$ of methanol. Sodium methanolate $(28 \mathrm{~mL}$ of a $5.4 \mathrm{M}$ solution in methanol) was added and the reaction mixture was stirred for 5 minutes at room temperature. Methyl iodide $(2.6 \mathrm{~mL}$, $41.3 \mathrm{mmol}, 1.1 \mathrm{eq}$ ) was added and the reaction mixture was stirred for an hour at room temperature. A white precipitate was formed. The reaction mixture was neutralized with potassium hydrogen sulfate, the product was extracted with ethyl acetate, dried over sodium sulfate and the solvent was evaporated. We obtained $7.3 \mathrm{~g}$ (31.0mmol, 83\%) of colorless oil.

\section{Cys(Me) OH·TFA}

Boc Cys(Me) OH $(7.0 \mathrm{~g}, 29.7 \mathrm{mmol})$ was dissolved in $80 \mathrm{~mL}$ of TFA:DCM (1:1) and the reaction mixture was stirred at room temperature for an hour. The solvent was evaporated and the product was used without any further purification.

\section{Fmoc Cys(Me) OH}

Cys(Me) OH·TFA $(3.2 \mathrm{~g}, 12.8 \mathrm{mmol})$ was added to $30 \mathrm{~mL}$ of water. Triethylamine was added till obtention of $\mathrm{pH} 9.0$ 9.5. Fmoc $O$ succinimidyl (4.3g, $12.8 \mathrm{mmol}$ ) dissolved in $60 \mathrm{~mL}$ of acetonitrile was 
added rapidly to the aqueous solution of amino acid. The reaction mixture was stirred at room temperature for 30 minutes. During this time, the $\mathrm{pH}$ was maintained between 9.0 and 9.5 by the addition of triethylamine. The reaction mixture was concentrated and the excess of Fmoc $O$ succinimidyl was extracted with diethyl ether. The water phase was neutralized with $1 \mathrm{M}$ potassium hydrogen sulfate and the product was extracted with diethyl acetate. The combined organic layers were washed with $1 \mathrm{M}$ potassium hydrogen sulfate, water and brine, dried over sodium sulfate and the solvent was evaporated. The product was purified by chromatography (silica, DCM: $\mathrm{MeOH}=19: 1)$ to give $3.9 \mathrm{~g}(10.9 \mathrm{mmol}, 85 \%)$ of a white solid. The synthesis of the Fmoc-Cys(Me)-OH building block was first necessary. This was achieved in 4 steps from cysteine following standard procedures, i.e. Boc protection of the amine, followed by methylation with methyl iodide in the presence of a base, cleavage of the Boc protecting group and finally Fmoc protection of the amine

\section{$\mathrm{R}_{\mathrm{f}}($ silica, $\mathrm{DCM}: \mathrm{MeOH})=0.5$}

${ }^{1} \mathrm{H} \mathrm{NMR}\left(\mathrm{CHCl}_{3}, 300 \mathrm{MHz}\right): \delta=2.08\left[\mathrm{~s}, 3 \mathrm{H}, \mathrm{S} \mathrm{CH}_{3}\right], 2.712 .79$ [dd, $\left.{ }^{3} \mathrm{~J}=9.5 \mathrm{~Hz},{ }^{2} \mathrm{~J}=13.6 \mathrm{~Hz}, 1 \mathrm{H}, \mathrm{S} \mathrm{CH}_{2}\right], 2.86-2.93\left[\mathrm{dd},{ }^{3} \mathrm{~J}=4.7 \mathrm{~Hz},{ }^{2} \mathrm{~J}=13.8\right.$ $\left.\mathrm{Hz}, 1 \mathrm{H}, \mathrm{S} \mathrm{CH}_{2}\right], 4.144 .34\left[\mathrm{~m}, 4 \mathrm{H}, \mathrm{CH}_{\alpha}+\mathrm{CH}\right.$ (Fmoc) $+\mathrm{CH}_{2}$ (Fmoc)], $7.317 .36\left[\mathrm{t},{ }^{3} \mathrm{~J}=7.3 \mathrm{~Hz}, 2 \mathrm{H}, \mathrm{Ar} \mathrm{CH}\right.$ (Fmoc)], $7.407 .45\left[\mathrm{t},{ }^{3} \mathrm{~J}=7.2 \mathrm{~Hz}\right.$, 2H, Ar CH (Fmoc)], 7.737 .76 [d, ${ }^{3} \mathrm{~J}=7.2 \mathrm{~Hz}, 2 \mathrm{H}, \mathrm{Ar}$ CH (Fmoc)], 7.88 $7.91\left[\mathrm{~d},{ }^{3} \mathrm{~J}=7.2 \mathrm{~Hz}, 2 \mathrm{H}, \mathrm{Ar} \mathrm{CH}\right.$ (Fmoc) $]$ ppm.

\section{Peptide synthesis}

Peptide amides were synthesized on TentaGel S RAM resin and peptide acids were synthesized on TentaGel S PHB following the standard protocol for Fmoc solid phase peptide synthesis [44]. For the TentaGel S RAM resin, a flask equipped with a filter was charged with TentaGel S RAM resin (1.0g, theoretical loading $=0.22 \mathrm{mmol} / \mathrm{g}$ ) and NMP $(10 \mathrm{~mL})$. A flow of nitrogen was passed through the suspension and the resin was allowed to swell for 30 minutes. The Fmoc protecting groups were cleaved by treatment of the resin with a $20 \%$ piperidine solution in NMP for 8 minutes. The treatment was repeated twice. The cleavage solutions were collected. The resin was washed 3 times with NMP and the washing solutions were added to the cleavage solutions. The loading of the resin was determined by measurement of the UV absorbance of the collected solutions at $\lambda=301 \mathrm{~nm}$. The loading was determined to be $0.21 \mathrm{mmol} / \mathrm{g}$.

The TentaGel S PHB resin was loaded according to the Sieber protocol. TentaGel S PHB (1g, theoretical loading $0.31 \mathrm{mmo} / \mathrm{g}$ ) and Fmoc Ala $\mathrm{OH}$ (772mg, 2.48mmol, 8eq) were dried overnight over phosphorus pentoxide. DMF $(5 \mathrm{~mL})$ was added and the reaction mixture was stirred for 10 minutes under nitrogen. Pyridine $(0.4 \mathrm{~mL}, 4.96 \mathrm{mmol}, 16 \mathrm{eq})$ and 2,6 dichloro benzoyl chloride $(0.8 \mathrm{~mL}$, $4.96 \mathrm{mmol}, 16 \mathrm{eq}$ ) were added and the reaction mixture was shaken over the weekend at room temperature under nitrogen ( 60 hours). The solvent was removed by filtration and the resin was washed 3 times with DMF and 3 times with DCE. The remaining free hydroxyl functions were capped with benzoyl chloride. DCE $(10 \mathrm{~mL})$ was added to the resin, followed by pyridine $(0.4 \mathrm{~mL}, 4.96 \mathrm{mmol}, 16 \mathrm{eq})$ and benzoyl chloride $(0.6 \mathrm{~mL}, 4.96 \mathrm{mmol}, 16 \mathrm{eq})$. The resin was shaken at room temperature for 2 hours under nitrogen. The solvent was removed by filtration and the resin was washed 3 times with DCE. By cleavage of the Fmoc protecting groups the loading of the resin was determined to be $0.22 \mathrm{mmol} / \mathrm{g}$. Fmoc protecting groups were cleaved by treatment of the resin with $20 \%$ piperidine in NMP (3 times for 8 minutes).

Amino acid couplings were performed in NMP using 4eq of amino acids, 4eq of BOP and 8eq of DiPEA relative to the loading of the resin for 1 hour. The completion of the reaction was checked by Kaiser Test. If necessary, the $N$ - terminus was acetylated by reaction with acetic anhydride (0.5 M), DiPEA (0.125M) and HOBt $(0.015 \mathrm{M})$ twice for 20 minutes.

The peptides were cleaved from the resin using a cocktail made of TFA $/ \mathrm{H}_{2} \mathrm{O} / \mathrm{TIS} / \mathrm{TES}$ 90:5:2.5:2.5 v/v/v/v when cysteine was present in the peptide sequence or a cocktail made of TFA/ $\mathrm{H}_{2} \mathrm{O} / \mathrm{TIS}$ 95:2.5:2.5 $\mathrm{v} / \mathrm{v} / \mathrm{v}$ when no cysteine was present in the sequence. The resin was shaken for 4 hours in the cocktail solution. The resin was removed by filtration and the peptide was obtained by precipitation from $n$-hexane/MTBE $1: 1 \mathrm{v} / \mathrm{v}$, followed by lyophilization. Replacements of amino acids, compared to the reference peptide such as citrulline, Methyl-Cysteine, histidine, tyrosine and phenylalanine where performed in the same way. Labeled peptides were prepared by incorporating the label during solid-phase synthesis and are incorporated onto the amino terminus of the peptide chain.

As a reference peptide, batches of the synthetic peptide corresponding to residues 1-11 of hLF [GRRRRSVQWCA; $\left(\mathrm{C}_{56} \mathrm{H}_{95} \mathrm{~N}_{25} \mathrm{O}_{14} \mathrm{~S}\right.$, Mw. 1,374 Da; purity of 98\%] were purchased from Pepscan, Lelystad, the Netherlands. A scrambled hLF(1-11) peptide comprising alanines at position 2, 3, 6 and 10 [GAARRAVQWAA; Mw. 1,156 Da.] was included as a negative control.

\section{Peptide purification}

Synthetic peptides were purified by reverse phase high performance liquid chromatography (RP-HPLC) using a water/ methanol mixture as eluent. Purity of the peptides usually exceeded $88 \%$ as determined by mass spectroscopy. Contaminating traces of lipopolysaccharides (LPS) in the peptide preparations were lower than 20pg./mL, as assessed by Limulus assay (Chromogenix, Molndal, Sweden). Stocks of the peptides at a concentration of $1 \mathrm{mg} / \mathrm{mL}$ of $0.01 \%$ acetic acid (Hac) were stored at $-70{ }^{\circ} \mathrm{C}$ and dried in a Speed-Vac (Savant Instruments Inc., Farmingdale, NY) prior to use. For the in vitro killing assays, peptides were dissolved in $10 \mathrm{mM}$ sodium phosphate buffer ( $\mathrm{NaPB}$ ) or sterile saline for in vivo experiments.

\section{Peptide characterization}

Peptides were characterized by analytical HPLC on a Shimadzu 10A VP using a Alltech Prosphere C18 $(250 \times 4.6 \mathrm{~mm}$, pore size: $300 \AA$ A, particle size: $5 \mu \mathrm{m}$ ) at a flow rate of $1.0 \mathrm{~mL} / \mathrm{min}$ and using a linear gradient of buffer B (0 - 30\% in 30min) in buffer A (buffer A: $0.1 \%$ TFA in $\mathrm{H}_{2} \mathrm{O} / \mathrm{MeCN} 95: 5 \mathrm{v} / \mathrm{v}$, buffer B: $0.1 \%$ TFA in $\mathrm{MeCN} /$ $\mathrm{H}_{2} \mathrm{O} 95: 5 \mathrm{v} / \mathrm{v}$ ) [45]. Electrospray ionization mass spectrometry was 
performed on a Shimadzu LCMS QP 8000 single quadrupole bench top spectrometer operating in a positive ionization mode.

\section{In vitro experiments}

Microorganisms: Source of C. albicans strain: Fluconazoleresistant C. albicans strain Y01-19 was purchased from Pfizer (Groton, Conn.). The yeast was identified using Candi select (Sanofi Pasteur, Paris, France) and confirmed by the pattern of sugar utilization (API, ID 32C, bioMerieux, Marcy l'Etoile, France) Fluconazole resistance was evaluated, as minimal inhibitory concentration (MIC) (MIC $>256 \mu \mathrm{g} / \mathrm{ml})$, using the Etest (AB Biodisk, Solna, Sweden). Three well-characterized Candida spp strains were purchased from American Type Culture Collection, Rockville, MD (ATCC), five strains from Hospital outbreaks were obtained from the LUMC (The Netherlands). Both Cryptococcus neoformans strains were purchased by the UMC (The Netherlands). As control for multidrug resistance Saccharomyces cerevisiae (ATCC) was used in this study. Furthermore, 12 fungal strains were tested for their in vitro activity to hLF(1-11) by the University of Perugia, Department of Pharmaceutical Sciences, Italy. The five type strains (CBS 94, CBS 138, CBS 562, CBS 604, CBS 2030) were obtained from Westerdijk Fungal Biodiversity Institute while the other strains were isolated from patient blood cultures in the two Italian Hospitals of Pisa and Udine. All the strains are included in Cemin Microbial Collection of the Microbial Genetics and Phylogenesis Laboratory (Cemin, Centre of Excellence on Nanostructured Innovative Materials for Chemicals, Physical and Biomedical Applications - University of Perugia). The antifungal resistances profiles of various (drug resistant) Candida strains are given in Table 1a. Staphylococcus aureus 10649 and Staphylococcus aureus 29213 ATCC were sensitive to a variety of antibiotics including methicillin (minimal inhibitory concentration, MIC $<1 \mathrm{mg} / \mathrm{L}$ ) and vancomycin (MIC $<0.5 \mathrm{mg} / \mathrm{L}$ ). Staphylococcus aureus 2141 a clinical isolate from the LUMC, the Netherlands was highly resistant to a variety of antibiotics including methicillin (MIC $>256 \mathrm{mg} / \mathrm{L}$ ) and vancomycin (MIC $>4 \mathrm{mg} / \mathrm{L}$ ). Staphylococcus epidermidis Type 2163, which was sensitive to a variety of antibiotics, was obtained from the VU Medical Center, Amsterdam, the Netherlands. Four well-characterized Acinetobacter baumannii strains from different locations in Europe were selected for this study. The strains had been identified as $A$. baumannii by validated genotypic methods including amplified ribosomal DNA restriction analysis (ARDRA) and by AFLP ${ }^{\mathrm{TM}}$ analysis. By these respective methods the 16S rDNA restriction profiles and the genomic fingerprints of strains are compared to those in libraries of rDNA restriction profiles and of AFLP fingerprints of reference strains of described genomic species. Strain RUH 134, RUH 875 and LUH 7312 were from hospital outbreaks. LUH 6034 (17C003 - Spain) was from a case of pneumonia. RUH 875 and RUH134 are the respective reference strains of European clone I and II, two groups of highly similar strains found in different outbreaks in hospitals in NW Europe. Pseudomonas aeruginosae LUH 7545, clinical isolate obtained from the LUMC the Netherlands and two clinical isolates Streptococcus mitis from ICU patients of University Medical Centre St. Radboud, Nijmegen.
Overnight cultures of bacteria and yeasts were prepared in brain heart infusion broth (BHI), Muller Hinton broth (MHB) or Sabouraud dextrose broth (SB) (Oxoid, Basingsto $\neg$ ke, UK) in a shaking water bath at $37^{\circ} \mathrm{C}$. The antibacterial resistances profiles of various (drug resistant) bacterial strains are given in Table $1 \mathrm{~b}$.

Virulent strains of bacteria or fungi were maintained by passage in Swiss mice (see section Mouse Model). Briefly, 0.5-2×106 colony forming units (CFU) bacteria were injected i.v. and $24 \mathrm{~h}$ thereafter the mice were sacrificed. The spleen was aseptically removed; homogenized and serial dilutions of the homogenate were plated onto diagnostic sensitivity test agar (DST; Oxoid). A single CFU was transferred into $25 \mathrm{~mL}$ of trypticase soy broth (TSB; Oxoid) and incubated for $24 \mathrm{~h}$ at $37{ }^{\circ} \mathrm{C}$ and aliquots of these suspensions containing about $1 \times 10^{9}$ virulent bacteria per $\mathrm{mL}$ of TSB were stored at $-70{ }^{\circ} \mathrm{C}$

Yeasts were cultured overnight at $37^{\circ} \mathrm{C}$ and sub-cultured for $2.5 \mathrm{~h}$ on a rotary wheel at $37^{\circ} \mathrm{C}$ in Sabouraud broth (Oxoid). Virulent strains of the yeast were obtained after two passages in Swiss mice. Briefly, about $1 \times 10^{5} \mathrm{CFU}$ of yeasts in $0.1 \mathrm{ml}$ of saline were injected into a tail vein and $24 \mathrm{~h}$ thereafter the mice were sacrificed. The spleen was aseptically removed; homogenized and serial dilutions of the homogenate were plated onto Sabouraud agar. A single CFU was transferred into $25 \mathrm{ml}$ of Sabouraud broth and incubated for $24 \mathrm{~h}$ at $37^{\circ} \mathrm{C}$ and aliquots of this suspension containing about $5 \times 10^{8}$ virulent yeasts $/ \mathrm{ml}$ were stored in Microbank cryovials (Pro-Lab, diagnostics, Canada) at $-70^{\circ} \mathrm{C}$.

\section{Antifungal efficacy assays}

Fugal activities of the peptides against the various strains were quantitated using an in vitro microdilution procedure as described [46]. Stock solutions were prepared in water (fluconazole, voriconazol and caspofungine) or dimethyl sulfoxide (DMSO) (amphotericin). Further dilutions of each antifungal and hLF(111) were prepared with $1 / 4$ strength of medium [47]. RPMI 1640 medium (Sigma Chemical Co., St. Louis, Mo.) [48,49] without buffering supplement. The drug dilutions were dispend into 96well round-bottom polypropylene Low-Binding 96-well microtiter plates that were sealed and stored until needed. The yeast conidia or hyphen was adjusted to a concentration of 0.5-2.5 x 10 $30^{3} \mathrm{CFU} /$ mL (NCCLS. 2002- M27-A2) and an aliquot of $100 \mu$ l of this solution was added to each well of the microdilution plate. The plates were incubated at $35^{\circ} \mathrm{C}$ for $48 \mathrm{~h}$. Endpoints were determined by visual reading. The plates were agitated prior to reading to ensure that the contents were re-suspended. The MICs were determined according to a 0-to-4 scale (NCCLS M27-A). The MIC was defined as the lowest concentration of drug that produced a prominent decrease in turbidity compared with that of drug-free control (score $<2)$. For amphotericin B, the MIC was defined as the lowest concentration of the drug that completely inhibits the growth of the strain. Experiments were performed of at least three independent experiments. Values are presented as single data for clarity and ease of comparison of peptide efficacy. 


\section{Antifungal synergy studies}

In interaction studies, different strains of Candida were used to test the antifungal combinations by a chequer board titration method using 96-well polypropylene microtiter plates. The ranges of drug dilutions used were: $0.098-128 \mu \mathrm{g} / \mathrm{L}$ for hLF(1-11) and $0.048-256 \mu \mathrm{g} / \mathrm{L}$ for clinically used antifungal. The fractional inhibitory concentration (FIC) index for combinations of two antimicrobials was calculated according to the equation:

\section{FIC index $=$ FICA + FICB $=\mathrm{A} / \mathrm{MICA}+\mathrm{B} / \mathrm{MICB}$,}

where $\mathrm{A}$ and $\mathrm{B}$ are the MICs of drug $\mathrm{A}$ and drug $\mathrm{B}$ in the combination, MICA and MICB are the MICs of drug A and drug B alone, and FICA and FICB are the FICs of drug A and drug B. The FIC indexes were interpreted as follows: $<0.5$, synergy; $>0.5-1$, additive; 1-2 intermediaries; and $>2.0$, antagonism. Experiments were performed in triplicate. FIC values are presented as the median of each triplicate.

To study the contribution of hLF(1-11) and fluconazole as additional treatment against fluconazole resistant Candida albicans we performed an in vitro procedure [46]. Briefly, $10^{6} \mathrm{CFU}$ of fluconazole resistant Candida albicans were incubated with dose hLF(1-11) or $200 \mu \mathrm{g}$ fluconazole /ml and combinations thereof. Additional treatments were respectively added after 5 minutes or $2 \mathrm{~h}$ later and incubated for 6 and $24 \mathrm{~h}$ at $37^{\circ} \mathrm{C}$. Data are means from at least three independent series of experiments. Values are presented as single data for clarity and ease of comparison efficacy.

\section{Antibacterial efficacy assays}

Bacteria were grown on agar plates for $18-24 \mathrm{~h}$ at $37^{\circ} \mathrm{C}$. For most bacterial strains, Muller Hinton broth was used. The growth of some bacterial strains required additives or changes in the medium, and for this purpose they were cultured in the conditions recommended by the ATTC. Cell concentrations were estimated by measuring the ultraviolet absorbance at $600 \mathrm{~nm}$ and applying the formula CFU/ml$\mathrm{A} 600\left(3.8 \times 10^{8}\right)$, where CFU is the number of colony-forming units. The suspension was diluted in the same media used for the growth in order to reach $4 \times 10^{5} \mathrm{CFU} / \mathrm{ml}$. The MIC of each antimicrobial compounds against the selected microorganisms was determined by broth dilution method in a round-bottomed polypropylene LowBinding 96-well microtiter plate. Twenty microliter aliquots of $1 \mathrm{mg} / \mathrm{mL}$ concentrated peptide compounds in sterilized water were added to each well that contained $180 \mu$ one-fourth strength RPMI 1640 Medium + Glutamax (Gibco 61870) [47-50]. Serial dilutions were made by transfer of $100 \mu$ to next well. Thereafter $100 \mu \mathrm{l}$ of $105 \mathrm{CFU} / \mathrm{ml}$ of the test microorganism was added to each well. Two controls were set on each plate: the bacterial inoculum without any antimicrobial compound for determining the bacterial growth, medium not inoculated for sterility control. The plate was incubated at $37^{\circ} \mathrm{C}$ overnight. Bacterial cell growth was assessed by measuring the optical density of the culture at $600 \mathrm{~nm}$ on a micro plate reader. The MIC was calculated as the lowest antibiotic concentration at which growth was inhibited (inhibitory concentration $\mathrm{IC}_{90}$ ).

\section{In vivo experiments}

Mouse model: Animal studies were conducted at the Health Sciences Laboratory Animal Services facility at the University of Alberta and are conducted in accordance with the guidelines set out by the Canadian Council on Animal Care. All procedures for these studies were approved by the University Animal Policy and Welfare Committee. Specific pathogen-free, female Swiss mice ICO OF1, white, $\approx 20-25 \mathrm{~g}$ (Charles River) 8-10 weeks old were used in this study. The animals, housed in cages of five mice per group and fed with standard rodent chow ad libitum, were allowed to acclimate for 1 week before active experimentation. During the course of the experiments, animals were observed thrice daily for signs of drug-related morbidity or morality. Mice that became immobile or otherwise showed signs of severe illness were humanely terminated and recorded as dying on the following day. Analgesics were not administered to these animals, because the possibility of drug-drug interactions and their influence on the outcome of the study were unknown. Instead, these animals were sacrificed by $\mathrm{CO}_{2}$ exposure followed by cervical dislocation.

\section{Treatment of disseminated fluconazole-resistant Candida albicans infections in neutropenic mice}

Mice were rendered neutropenic by an intraperitoneal (i.p.) injection of $100 \mathrm{mg} / \mathrm{kg}$ of cyclophosphamide (Sigma-Aldrich Chemie $\mathrm{BV}$ ) at days -3 and 0 of infection to produce severe neutropenia at the day the of infection. Blood cell counts were randomly performed to confirm neutropenia. Approximately $1 \times 10^{5} \mathrm{CFU}$ fluconazoleresistant C. albicans in $0.1 \mathrm{ml}$ of saline were aseptically injected into a tail vein. Twenty-four $h$ thereafter, mice received an i.v. injection with different doses of hLF(1-11) up to $40 \mu \mathrm{g} / \mathrm{kg}$ body weight. To determine the normal outgrowth posit a group of mice received saline only. The control peptide and fluconazole were included as negative controls as well. Fluconazole (Pfizer Inc. New York, NY) dissolved in saline at a concentration of $50 \mathrm{mg} / \mathrm{ml}$ was given subcutaneously to mice at $5 \mathrm{mg} / \mathrm{kg}$ body weight. Amphotericin B (0.5 $\mu \mathrm{g} / \mathrm{kg}$ i.p.; Bristol-Meyers Squibb Group, Quebec, Canada) was included as a positive control. For synergy experiments, mice received an i.v. injection with a sub-optimal dose of $0.004 \mu \mathrm{g} / \mathrm{kg}$ hLF(1-11) and different doses of fluconazole up to 200mg. After $18 \mathrm{~h}$ of treatment, the animals were sacrificed and the kidneys removed, weighed, and homogenized and the number of viable yeasts was determined by plating serial dilutions of each sample on Sabouraud agar. The detection limit was set at 400CFU. Results, expressed as the number of CFU per gram of kidney, are medians of four- five animals per group of three series of experiments. In some experiments, one kidney was used for microbiological analysis of the antifungal activities of the peptide whereas the other one was processed for histological analysis.

\section{Histology}

Tissue samples taken from the animals were fixed in $70 \%$ alcohol for $24 \mathrm{~h}$ and then in $4 \%$ formaldehyde, processed and embedded in paraffin wax. Next, $5 \mu$ m-thick sections were stained 
with Grocott's modification of Gomori's methanamine-silver stain and counterstained with $0.2 \%$ light green (Fluka Sigma-Aldrich) for microscopic examination of the localization and severity of infectious foci as well as the morphology of C. albicans at the site of infection as a result of the antimicrobial intervention.

\section{MRSA infections in neutropenic mice}

Table 1a: Contribution of $h L F(1-11)$ to the fungal activity against fungal strains.

\begin{tabular}{|c|c|c|c|}
\hline \multirow{2}{*}{ Strain } & \multicolumn{3}{|c|}{ Mean MIC $_{90}$ in $\mu \mathrm{g} / \mathrm{mL}$, by Agent ${ }^{\text {a }}$} \\
\hline & hLF (1-11) & Fluconazole & Amphotericin B \\
\hline C. albicans Y01-19 & 12.5 & $>256$ & 1 \\
\hline C. albicans AA (LUMC) & 25.0 & 2 & 2 \\
\hline C. albicans ATCC 10231 & 25.0 & 2 & 1 \\
\hline C. albicans ATCC 90028 & 12.5 & 2 & 2 \\
\hline C. albicans CBS-562 (Perugia) & 25.0 & 2 & 2 \\
\hline C. albicans CMC-1968 (Perugia) & 25.0 & 2 & 1 \\
\hline C. parapsilosis (LUMC) & 12.5 & 4 & 1 \\
\hline C. parapsilosis ATCC 22019 & 12.5 & 4 & 1 \\
\hline C. parapsilosis CBS-604 (Perugia) & 25.0 & 4 & 2 \\
\hline C. parapsilosis CMC-2039 (Perugia) & 25.0 & 4 & 2 \\
\hline C. krusei (LUMC) & 25.0 & 32 & 1 \\
\hline C. krusei CMC-2002 (Perugia) & 25.0 & 32 & 2 \\
\hline C. glabrata (LUMC) & 25.0 & 32 & 2 \\
\hline C. glabrata CBS-138 (Perugia) & 25.0 & 32 & 1 \\
\hline C. glabrata CMC-1933 (Perugia) & 25.0 & 32 & 2 \\
\hline C. tropicalis (LUMC) & 25.0 & 64 & 1 \\
\hline C tropicalis CBS-94 (Perugia) & 50.0 & 64 & 1 \\
\hline C tropicalis CMC-2041 (Perugia) & 50.0 & 64 & 2 \\
\hline C. lusitaniae CMC-1944 (Perugia) & 50.0 & 1 & 2 \\
\hline Crypt. neoform. WT (UMC) & 12.5 & 4 & 0.5 \\
\hline Crypt. neoform. $\triangle S K N 7$ (UMC) & 6.3 & 4 & 0.5 \\
\hline Saccharomyces cerivisiae ATCC 2601 & 25.0 & nd & nd \\
\hline Saccharomyces cerevisiae CMC-520 (Perugia) & 50.0 & 16 & 0.5 \\
\hline M. guilliermondii CBS-2030 (Perugia) & 50.0 & 8 & 1 \\
\hline
\end{tabular}

${ }^{a}$ MIC values were determined in RPMI 1640 + Glutamax one-fourth strength of the broth as assay medium [47]. Yeast experiments; $1 \times 10^{5} \mathrm{CFU}$ of various strains/ml were incubated for $24-48 \mathrm{~h}$ at $37{ }^{\circ} \mathrm{C}$ into one-fourth medium of RPMI 1640 with the previous concentrations of $\mathrm{hLF}(1-11)$, respectively. As controls various strains cells were incubated for $24-48 \mathrm{~h}$ at $37{ }^{\circ} \mathrm{C}$ with no agent, and then growth was monitored by using spectrophotometer at $620 \mathrm{~nm}$. Results are means of at least three independent experiments. ND $=$ Not done. Representative single assay data are given rather than a range for clarity and ease of comparison of peptide efficacy.

To study the synergistic antimicrobial effect of hLF(1-11) the peptide was injected into mice bearing infections with MRSA bacteria. Mice were rendered neutropenic by an intraperitoneal (i.p.) injection of $100 \mathrm{mg} / \mathrm{kg}$ of cyclophosphamide at days -3 and 0 of infection to produce severe neutropenia at the day of infection (see above). Approximately $2 \times 10^{6}$ CFU MRSA strain 2141 in $0.1 \mathrm{ml}$ of saline were aseptically injected into the right thigh muscle. Twenty-four hours thereafter, mice received an i.v. injection with different doses of hLF(1-11) up to $40 \mu \mathrm{g} / \mathrm{kg}$ body weight. For synergy experiments, mice received an i.v. injection with a suboptimal dose of $0.004 \mu \mathrm{g} / \mathrm{kg}$ hLF(1-11) and two higher doses of $\mathrm{hLF}(1-11)$ in combination with an i.p. injection of $0.0625 \mathrm{mg} / \mathrm{kg} /$ mouse vancomycin.
The control peptide and vancomycin were included as negative and positive controls as well. Vancomycin (Vancomycin 500PCH, Vancomycinehydrochloride, Fresenius Kabi, Toronto, Ontario, Canada) dissolved in saline at a concentration of $0.0625 \mathrm{mg} / \mathrm{kg} /$ mouse was given intraperitoneal to the mice. Blood cell counts were randomly performed to confirm neutropenia. Twenty-four hours later mice were sacrificed, blood was collected by heart puncture in citrate tubes and the right thigh muscle was removed. Thigh muscles were weighed and homogenized using an UltraTurrax $($ and dilutions of the homogenate were prepared in saline to determine the number of viable bacteria. Limiting dilutions were plated onto agar plates and two days later the number of MRSA 2141 CFU were determined for each individual mouse as an indication 
of bactericidal activity of the compound. During the course of the experiments, randomly tests were performed to determine if the bacteria used were still oxacillin resistant to oxacillin. For this purpose Staphaurex ${ }^{\circledR}$ (Remel Europe Ltd., Crossways, UK) and

\section{Statistical analyses}

Table 1b: Contribution of $\mathrm{hLF}(1-11)$ to the bacterial activity against bacterial strains.

\begin{tabular}{|c|c|}
\hline \multirow{2}{*}{ Strain } & 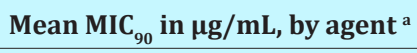 \\
\hline & hLF(1-11) \\
\hline S. aureus ATCC 10649 & 1.6 \\
\hline S. aureus ATCC 29213 & 3.1 \\
\hline S. epidermidis Type 2163 & 1.6 \\
\hline MRSA Type 2141 (LUMC) & 3.1 \\
\hline E.coli M1CK (LUMC) & 6.3 \\
\hline A. baumannii LUH6034 & 12.5 \\
\hline A. baumannii LUH 7312 & 12.5 \\
\hline A. baumannii RUH 134 & 12.5 \\
\hline A. baumannii RUH 875 & 12.5 \\
\hline P.aeruginosae LUH7545 & 12.5 \\
\hline K.pneumoniae L43816 & 12.5 \\
\hline Strep.mitis 32 (RadboudUMC) & 6.3 \\
\hline Strep.mitis 33 (RadboudUMC) & 6.3 \\
\hline
\end{tabular}

${ }^{a}$ MIC values were determined in RPMI 1640 + Glutamax one-fourth strength of the broth as assay medium [47]. The media were selected based on an optimal compromise between the growth of individual strains and peptide activity. The incubation temperature was $37^{\circ} \mathrm{C}$ and the incubation time was $16-24 \mathrm{~h}$. The assays were repeated three of four times; Here representative single assay data are given rather than a range for clarity and ease of comparison of peptide efficacy.
Differences between the results of the various treatments were analysed using GraphPad Prism. Two sided p-values are reported and the level of significance was set at $\mathrm{p}<0.05$. Pearson's correlation coefficient was used to assess the correlation between T/NT and the number of viable bacteria. Scheffe's test for Lmean was used to compare correlation (type I), confidence interval and clinical significance between the vivo experiments.

\section{Results}

The peptides discussed in this report were synthesized by conventional solid phase methods. Purity of all synthetic peptides exceeded $<95 \%$, as determined by reverse-phase highperformance liquid chromatography. Peptides were diluted to stock concentrations of $1 \mathrm{mg} / \mathrm{mL}$ of $0.01 \%$ acetic acid (pH 3.7) and stored at $-20^{\circ} \mathrm{C}$.

\section{In vitro experiments}

$\mathrm{hLF}(1-11)$ is a 11 mer peptide with a free carboxylic function at its $C$-terminus and a free amine at its $N$-terminus. In this study, it is active against various gram-positive bacteria (Staphylococcus aureus, methicillin resistant Staphylococcus aureus, Staphylococcus epidermidis and Streptococcus mitis), gram-negative bacteria (Acinetobacter baumannii, Pseudomonas aeroginosae, Klebsiella
ORSAB $($ + supplements (Oxoid Ltd., Basingstoke, UK) were used. In vivo antibiotic activity was determined by a CFU reduction of $>90 \%$ ( 1 log reduction) in comparison to the negative control (vehicle only). pneumoniae and Escherichia coli) and fungi (Candida albicans). The MIC values for gram-positive bacteria range from 1.6 (for $S$. aureus and MRSA) to $6.3 \mu \mathrm{g} / \mathrm{mL}$ (for S. mitis). The MIC values for gramnegative bacteria are from equal to 4 times higher and range from 6.3 (for E. coli) to $12.5 \mu \mathrm{g} / \mathrm{mL}$ (for A. baumannii, P. aeruginosae and K. pneumoniae). Finally the MIC values for fungal strains range from $6.3 \mu \mathrm{g} / \mathrm{mL}$ (Crypt. Neoformans $\Delta$ SKN7) to $50 \mu \mathrm{g} / \mathrm{mL}$ Candia spp (Table 1A \& 1B).

In order to investigate the utility of the $C$ - and $N$-terminus of hLF(1 11) for biological activity against various microorganisms, peptides with an amide at the $\mathrm{C}$ terminus and/or an acetylated $\mathrm{N}$ terminus were synthesised (hLF NC-03, hLF N11 and hLF C13). These peptides were compared to $h L F(1-11)$ for their biological activity against the previously cited gram-positive bacteria, gramnegative bacteria and yeasts (Table 2A \& 2B). The N-acetylated peptide showed a significant reduced activity against grampositive bacteria (MIC values of 3.1, 3.1, 6.3 and $12.5 \mu \mathrm{g} / \mathrm{mL}$ against S. aureus, MRSA, S. epidermidis and $S$. mitis respectively, compared to $1.6,1.6,3.1$ and $6.3 \mu \mathrm{g} / \mathrm{mL}$ for hLF(1-11) but equal to increased activity against gram-negative bacteria $(6.3,12.5,12.5$ and $6.3 \mu \mathrm{g} /$ $\mathrm{mL}$ against $A$. baumannii, P. aeruginosa, K. pneumoniae and E. coli respectively compared to $12.5,12.5,12.5$ and $6.3 \mu \mathrm{g} / \mathrm{mL}$ for $\mathrm{hLF}(1-$ 11) . 
Table 2a: Summary of in vitro activity of modified hLF1-11 derived peptides, structure relationship.

\begin{tabular}{|c|c|c|c|c|c|c|c|c|c|c|c|c|}
\hline $\begin{array}{l}\text { Compound/ } \\
\text { strain }\end{array}$ & S. aureus ${ }^{\mathrm{b}}$ & MRSA 2141 & S.epidermidis & Strep.mitis $^{c}$ & A. baumannii ${ }^{d}$ & Paeruginosae & K.pneumoniae & E.coli & C.albicans $^{e}$ & Amino acid sequence & MW & Remarks \\
\hline $\begin{array}{l}\text { hLF(1-11) } \\
\text { PS }\end{array}$ & 1.6 & 1.6 & 3.1 & 6.3 & 12.5 & 12.5 & 12.5 & 6.3 & 12.5 & GRRRRSVQWCA & 1374.6 & Reference Peptide \\
\hline $\begin{array}{l}\text { Scrambled } \\
\text { Peptide }\end{array}$ & $>100$ & $>100$ & $>100$ & $>100$ & $>100$ & $>100$ & $>100$ & $>100$ & $>100$ & GAARRAVQWAA & 1155.3 & $\begin{array}{c}\text { Control peptide, } \\
\text { Alanines at position } \\
2,3,6 \& 10\end{array}$ \\
\hline hLF NC-03 & 3.1 & 3.1 & 3.1 & 6.3 & 6.3 & 12.5 & 6.3 & 3.1 & 12.5 & $\begin{array}{c}(\mathrm{AcNH}) \\
\text { GRRRRSVQWCA(CONH2) }\end{array}$ & 1415.6 & $\begin{array}{l}\mathrm{N} \text {-acetylated and } \\
\mathrm{C} \text {-amidated }\end{array}$ \\
\hline hLF N 11 & 3.1 & 3.1 & 6.3 & 12.5 & 6.3 & 12.5 & 12.5 & 6.3 & 12.5 & (AcNH)GRRRRSVQWCA & 1416.6 & $\mathrm{~N}$-acetylated \\
\hline hLF N 12 & 3.1 & 6.3 & 3.1 & 12.5 & 6.3 & 12.5 & 12.5 & 12.5 & 12.5 & $\begin{array}{l}\text { GRRRRSVQWCA (no } \\
\text { protection) }\end{array}$ & 1373.7 & $\begin{array}{l}\text { Both sides not } \\
\text { protected }\end{array}$ \\
\hline hLF C 13 & 1.6 & 1.6 & 3.1 & 3.1 & 3.1 & 3.1 & 3.1 & 6.3 & 12.5 & GRRRRSVQWCA(CONH2) & 1373.6 & C-amidated \\
\hline hLF N 17 & 100 & 100 & 50 & 25 & 50 & 50 & 50 & 100 & 100 & GRRRRSVQWSA & 1358.5 & $\begin{array}{c}\text { hLF(1-11) (position } \\
10 \text { Serine) }\end{array}$ \\
\hline hLF N 26 & 6.3 & 3.1 & ND & ND & ND & ND & ND & 6.3 & 12.5 & Dimer of hLF(1-11) & 2745.2 & $\begin{array}{l}\text { Dimer, at position } \\
10 \text { (Cysteine) }\end{array}$ \\
\hline hLF S 43 & 1.6 & 1.6 & 6.3 & 12.5 & 12.5 & 12.5 & 12.5 & 3.1 & 12.5 & $\begin{array}{c}\text { FRRRRSVQWCK(Ac)- } \\
(\mathrm{CONH} 2)\end{array}$ & 1561.9 & $\begin{array}{l}\text { Mimetic of fishing } \\
\text { peptide }\end{array}$ \\
\hline hLF S 55 & 100 & 100 & 25 & 50 & 50 & 50 & 50 & 100 & 100 & $\begin{array}{l}\text { G-Cit-Cit-Cit-Cit- } \\
\text { SVQWCA(CONH2) }\end{array}$ & 1377.5 & $\begin{array}{l}\text { Arginine residues } \\
\text { replaced by neutral } \\
\text { citrulline residues }\end{array}$ \\
\hline hLF S 63 & 6.3 & 6.3 & ND & ND & ND & ND & ND & 50 & 50 & WCAGRRRRSVQ(CO-Npip) & 1441.7 & $\begin{array}{l}\text { Shifted peptide, } \\
\text { pyridine ring at } \\
\text { C-terminus }\end{array}$ \\
\hline hLF S 86 & 3.1 & 1.6 & 3.1 & 6.3 & 6.3 & 6.3 & 6.3 & 3.1 & 12.5 & $\begin{array}{l}\text { FRRRRSVQWCK(Bio)- } \\
\text { (CONH2) }\end{array}$ & 1657.0 & C-terminal biotin \\
\hline hLF S 87 & 3.1 & 3.1 & 12.5 & 25 & 25 & 25 & 25 & 6.3 & 25 & $\begin{array}{c}\text { GRRRRSVQWCK(Fluo)- } \\
\text { (CONH2) }\end{array}$ & 1789.0 & $\begin{array}{c}\text { Fluorescein moiety } \\
\text { at C-terminus }\end{array}$ \\
\hline hLF S 99 & 50 & 6.3 & 50 & 50 & 50 & 50 & 50 & 12.5 & 100 & GRRRRSVQWCmeA(CONH2) & 1387.6 & $\begin{array}{l}\text { Methyl-Cysteine: } \\
\text { unable to dimerize }\end{array}$ \\
\hline hLF S 103 & 12.5 & 6.3 & 12.5 & 50 & 25 & 50 & 50 & 25 & 50 & GRRRRSVQHCA(CONH2) & 1324.5 & $\begin{array}{c}\text { hLF(1-11) (position } \\
9 \text { Histidine) }\end{array}$ \\
\hline hLF S 104 & 6.3 & 3.1 & 6.3 & 25 & 12.5 & 12.5 & 12.5 & 12.5 & 25 & GRRRRSVQYCA(CONH2) & 1350.6 & $\begin{array}{c}\text { hLF(1-11) (position } \\
9 \text { Tyrosine) }\end{array}$ \\
\hline hLF S 105 & 3.1 & 1.6 & 3.1 & 12.5 & 12.5 & 6.3 & 6.3 & 6.3 & 25 & GRRRRSVQFCA(CONH2) & 1334.6 & $\begin{array}{l}\text { hLF(1-11) (position } \\
9 \text { Phenylalanine) }\end{array}$ \\
\hline
\end{tabular}

${ }^{\mathrm{a} M I C}$ values were determined in RPMI 1640 + Glutamax one-fourth strength of the broth as assay medium [47].

bMIC values for S. aureus ATTC 10649 and S. aureus ATTC 29213 were equal.

'MIC values for Streptococcus mitis 032 and Streptococcus mitis 033 were equal.

dMIC values for Acinetocater baumannii strains LUH6034, LUH7312, RUH134 and RUH875 were comparable.

eMIC values for Candida albicans Y01-19 and Candida albicans ATTC 90028 were comparable

The media were selected based on an optimal compromise between the growth of individual strains and peptide activity. The incubation temperature was $37{ }^{\circ} \mathrm{C}$ and the incubation time was 16-24h. The assays were repeated three of four times; here representative single assay data are given rather than a range for clarity and ease of comparison of peptide efficacy.

$\mathrm{ND}=$ not done 
Table 2b: Prediction of bioactivity and cell penetrating of synthesised hLF (1-11) based peptides.

\begin{tabular}{|c|c|c|}
\hline Peptide & $\begin{array}{c}\text { Prediction of } \\
\text { bioactivity }^{\text {a }}\end{array}$ & Prediction of Cell Penetrating \\
\hline hLF A 1 & 0.29 & 0.801 \\
\hline hLF A 2 & 0.40 & 0.669 \\
\hline hLF A 3 & 0.42 & 0.657 \\
\hline hLF A 4 & 0.46 & 0.647 \\
\hline hLF A 5 & 0.39 & 0.643 \\
\hline hLF A 6 & 0.40 & 0.820 \\
\hline hLF A 7 & 0.44 & 0.752 \\
\hline hLF A 8 & 0.46 & 0.765 \\
\hline hLF A 9 & 0.20 & 0.734 \\
\hline hLF A 10 & 0.21 & 0.801 \\
\hline hLF C 13 & 0.38 & 0.757 \\
\hline hLF N 17 & 0.19 & 0.722 \\
\hline hLF S 55 & 0.80 & 0.088 \\
\hline hLF S 63 & 0.33 & 0.771 \\
\hline hLF S 86 & 0.43 & 0.785 \\
\hline hLF S 103 & 0.18 & 0.650 \\
\hline hLF S 104 & 0.19 & 0.620 \\
\hline hLF S 105 & 0.33 & $0-14$ \\
\hline
\end{tabular}

aPrediction of bioactivity based on a novel N-to-1 neutral network (PeptideRanker). Peptides ranked according to the algorithm's belief that they resemble a bioactive peptide. It does not break down the sequence to look for subsequences within the peptide.

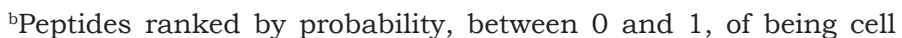
penetrating i.e. 1 very likely to be cell penetrating, 0 very unlikely to be cell penetrating.

The $\mathrm{C}$ amidated peptide showed an equal or increased activity against gram-positive bacteria (MIC values of 1.6, 1.6, 3.1 and 3.1 $\mu \mathrm{g} /$ $\mathrm{mL}$ against $S$. aureus, MRSA, $S$. epidermidis and $S$. mitis respectively, compared to $1.6,1.6,3.1$ and $6.3 \mu \mathrm{g} / \mathrm{mL}$ for hLF(1-11) and an increased activity against gram-negative bacteria (3.1, 3.1, 3.1 and $6.3 \mu \mathrm{g} / \mathrm{mL}$ against $A$. baumannii, P. aeruginosa, K. pneumoniae and E. coli respectively compared to $12.5,12.5,12.5$ and $6.3 \mu \mathrm{g} / \mathrm{mL}$ for hLF(1-11) . The MIC values for the peptide that is $N$-acetylated and $C$ amidated were coherent with the results of the just $\mathrm{N}$-acetylated or just $\mathrm{C}$ amidated peptides, i.e. the activity of this peptide against gram-positive bacteria was equal or lower than the one of hLF(111) and its antimicrobial activity against gram-negative bacteria was higher. Protection of the $\mathrm{C}$ and/or $\mathrm{N}$ terminus did not affect at all the antifungal activity of the peptide against the yeast $C$. albicans (MIC value of $12.5 \mu \mathrm{g} / \mathrm{mL}$ for all observations).

Considering the improvement in activity obtained with the $C$ amidated peptide, the next peptides that were synthesised for this study were all C amidated. After investigation of the importance of the $N$ and $C$ termini for biological activity, we turned our intention to the importance of the side chains. For this purpose, 10 other peptides were synthesised where each amino acid has been, one by one, replaced by the nonpolar amino acid alanine (hLF A1 hLF A10). Replacement of glycine by alanine led to a peptide with a similar activity against gram-positive as well as against gramnegative bacteria and yeasts. Replacement of the serine (hLF A6), valine (hLF A7) or glutamine (hLF A8) residue by alanine led also to peptides with similar activities against yeasts (MIC values of 12.5 or $25 \mu \mathrm{g} / \mathrm{mL}$ against $C$. albicans compared to $12.5 \mu \mathrm{g} / \mathrm{mL}$ for hLF(1 11)). Their biological activity against gram-positive bacteria was also similar with MIC values of 1.6 or $3.1 \mu \mathrm{g} / \mathrm{mL}$ against $S$. aureus compared to $1.6 \mu \mathrm{g} / \mathrm{mL}$ for $\mathrm{hLF}(1-11)$ and MIC values of $1.6 \mu \mathrm{g} /$ $\mathrm{mL}$ against MRSA compared to $1.6 \mu \mathrm{g} / \mathrm{mL}$ for $\mathrm{hLF}(1-11)$. However replacement of the glutamine residue by alanine led to a decrease in activity in the case of S. epidermidis (MIC value of $12.5 \mu \mathrm{g} / \mathrm{mL}$ compared to $3.1 \mu \mathrm{g} / \mathrm{mL}$ for $\mathrm{hLF}(1-11)$ and replacement of the valine residue led to a decrease in activity in the case of $S$. mitis (MIC value of $25 \mu \mathrm{g} / \mathrm{mL}$ compared to $6.3 \mu \mathrm{g} / \mathrm{mL}$ for $\mathrm{hLF}(1-11)$. The activity against gram-negative bacteria was not affected by the replacement of serine, valine or glutamine residue by alanine (Table 3) (Figure 1).

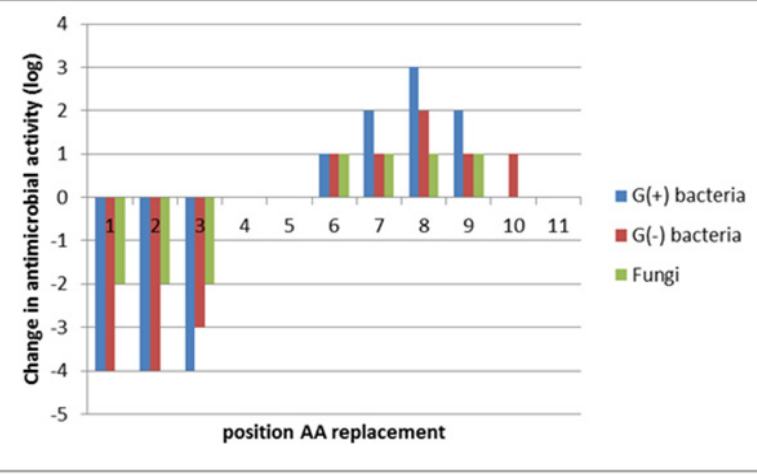

Figure 1: Change in antimicrobial activity. Bar-figure with replacement of the AA on the $\mathrm{x}$-axis versus on the $\mathrm{y}$-axis the (negative or positive) effect on either gram positive bacteria, gram negative bacteria, or fungi. Expressed as log reduction $(-) /$ enhancement $(+)$.

Replacement of the arginine residues by alanine showed the importance of these positively charged residues for biological activity. But this importance varies for the various microorganism tested. Indeed when the first arginine was replaced by alanine, the MIC values showed an increased effect in the case of grampositive bacteria. In the case of gram-negative bacteria, only $E$. coli was sensitive to the replacement of the first arginine residue which resulted to an increase in the MIC value. The enhanced antimicrobial activity appears mainly to the changes in properties such as hydrophobicity and amphipatic propensity.

Replacing the second arginine residue by alanine resulted also in a decrease in activity compared to hLF(1-11) since the MIC values against gram-positive bacteria were 4 to 8 times higher. Gram-negative bacteria were more sensitive to the replacement of the second arginine than to the replacement of the first arginine by alanine ( 2 to 4 fold increase in the MIC values), while C. albicans 
was less sensitive for this change (a 2 fold increase in the MIC value). When the third arginine residue was replaced by alanine, a significant decrease in biological activity was only observed for gram-negative bacteria with a 4 fold increase in the MIC value for $P$. aeruginosa and $K$. pneumoniae. Replacement of the fourth arginine residue by alanine did not affect the biological activity of the peptide on gram-negative bacteria and yeasts. The fourth arginine residue does not show significant importance for microbial activity.
The activity on gram-positive bacteria was only sensitive to this modification against $S$. mitis. In addition to those peptides with alanine residue instead of arginine, a peptide has been synthesised with 4 citrulline residues instead of the 4 arginine (hLF S55). This peptide showed a total loss of activity compared to hLF(1-11), which highlight the necessity of positively charged amino acids for biological activity, even for activity against yeasts (Table 2A).

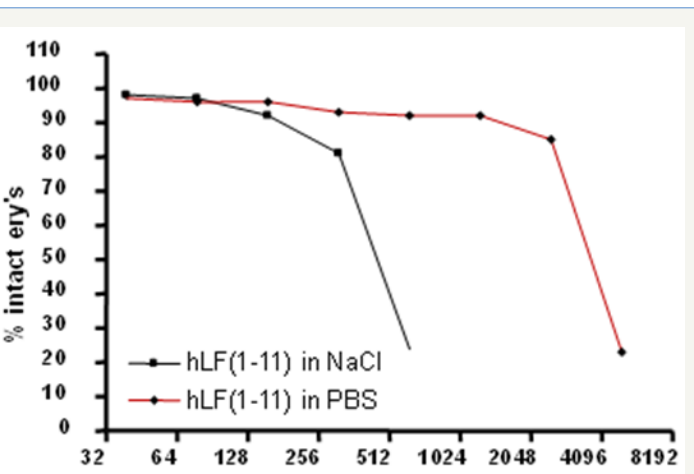

$\boldsymbol{\mu g} / \mathbf{m l}$

Figure 2: Heamolytic effect of hLF(1-11) (supporting). Effect of $h L F(1-11)$ solved into Phospahte buffered solution (PBS) and high salt buffered solution (NaCL) on mammalian cells (shown as percentage of intact human erythrocytes). Values represent absorption of light by haemoglobin from lysed erythrocytes. hLF(1-11) into PBS did not significantly alter the number of cells up to $2000 \mu \mathrm{g} / \mathrm{mL}$, but solved into $\mathrm{NaCL}$, haemolysis was already seen at concentration of $256 \mu \mathrm{g} / \mathrm{mL}$. Results represent at least three determinations in triplicate; average standard deviations were $5 \%$ (intact erythrocytes).

Table 3: In vitro activity of full Ala-scan synthesised $\mathrm{hLF}(1-11)$ based peptides against experimental fungal and bacterial strains.

\begin{tabular}{|c|c|c|c|c|c|c|c|c|c|c|c|}
\hline \multicolumn{12}{|c|}{$\mathrm{MIC}$ in $\mu \mathrm{g} / \mathrm{mL}^{\mathrm{a}}$} \\
\hline Peptide & C.albicas ${ }^{b}$ & S. aureus ${ }^{c}$ & $\begin{array}{l}\text { MRSA } \\
2141\end{array}$ & S.epidermidis & Strepmitis $^{d}$ & A. baumannii ${ }^{e}$ & P.aeruginosae & K.pneumoniae & E.coli & $\begin{array}{c}\text { Amino Acid } \\
\text { Sequence }\end{array}$ & MW \\
\hline & Fungi & Gr+ & Gr+ & Gr+ & Gr+ & GR- & GR- & GR- & GR- & & \\
\hline hLF A1 & 25 & 1.6 & 1.6 & 6.3 & 12.5 & 12.5 & 12.5 & 12.5 & 3.1 & ARRRRSVQWCA & 1386.75 \\
\hline hLF A2 & 100 & 12.5 & 12.5 & 12.5 & 25 & 12.5 & 12.5 & 25 & 50 & GARRRSVQWCA & 1287.67 \\
\hline hLF A3 & 25 & 6.3 & 6.3 & 25 & 25 & 25 & 50 & 50 & 25 & GRARRSVQWCA & 1288.49 \\
\hline hLF A4 & 25 & 3.1 & 3.1 & 6.3 & 12.5 & 25 & 50 & 50 & 12.5 & GRRARSVQWCA & 1288.49 \\
\hline hLF A5 & 12.5 & 3.1 & 3.1 & 6.3 & 25 & 12.5 & 25 & 25 & 6.3 & GRRRASVQWCA & 1288.49 \\
\hline hLF A6 & 12.5 & 3.1 & 1.6 & 3.1 & 12.5 & 12.5 & 12.5 & 25 & 3.1 & GRRRRAVQWCA & 1357.59 \\
\hline hLF A7 & 25 & 1.6 & 1.6 & 3.1 & 25 & 12.5 & 12.5 & 25 & 6.3 & GRRRRSAQWCA & 1348.54 \\
\hline hLF A8 & 25 & 1.6 & 1.6 & 12.5 & 12.5 & 25 & 25 & 25 & 3.1 & GRRRRSVAWCA & 1316.54 \\
\hline hLF A9 & 100 & 12.5 & 12.5 & 25 & 50 & 25 & 50 & 50 & 50 & GRRRRSVQACA & 1258.46 \\
\hline $\begin{array}{l}\text { hLF } \\
\text { A10 }\end{array}$ & 100 & 12.5 & 12.5 & 25 & 50 & 50 & 50 & 50 & 50 & GRRRRSVQWAA & 1341.53 \\
\hline
\end{tabular}

${ }^{a}$ MIC values were determined in RPMI 1640 + Glutamax one-fourth strength of the broth as assay medium [47].

${ }^{\mathrm{b}} \mathrm{MIC}$ values for Candida albicans YO1-19 and Candida albicans ATTC 90028 were comparable

${ }^{\mathrm{C}}$ MIC values for S. aureus ATTC 10649 and S. aureus ATTC 29213 were equal.

${ }^{\mathrm{d}} \mathrm{MIC}$ values for Streptococcus mitis 032 and Streptococcus mitis 033 were equal.

eMIC values for Acinetocater baumannii strains LUH6034, LUH7312, RUH134 and RUH875 were comparable.

The media were selected based on an optimal compromise between the growth of individual strains and peptide activity.

The assays were repeated four times; here representative single assay data are given rather than a range for clarity and ease of comparison of peptide efficacy.

Note: MIC values of hLF(1-11) activity performed by ENARE showed for 1) S.aureus 3.1(1.56 - 6.25), 2) E.coli 25(12.5-50) and for Klebsiella 50(50) $\mu \mathrm{g} / \mathrm{ml}$. 
The tryptophan residues were very important for the activity of the peptide. Indeed, replacement of the tryptophan residue by alanine led to a remarkable decrease in biological activity in the case of yeasts (MIC value of $100 \mu \mathrm{g} / \mathrm{mL}$ against $C$. albicans compared to $12.5 \mu \mathrm{g} / \mathrm{mL}$ for $\mathrm{hLF}(1-11)$ ), gram-positive (MIC values of 12.5 , 12.5, 25 and $50 \mu \mathrm{g} / \mathrm{mL}$ against $S$. aureus, MRSA, S. epidermidis and $S$. mitis respectively, compared to $1.6,1.6,3.1$ and $6.3 \mu \mathrm{g} / \mathrm{mL}$ for $\mathrm{hLF}(1-$ 11) ) and gram-negative bacteria $(25,50,50$ and $50 \mu \mathrm{g} / \mathrm{mL}$ against A. baumannii, $P$. aeruginosa, K. pneumoniae and E. coli respectively compared to $12.5,12.5,12.5$ and $6.3 \mu \mathrm{g} / \mathrm{mL}$ for hLF(1-11). Similarly, replacement of the cysteine residue by alanine led to an important decrease in biological activity for all the microorganisms tested ( 8 fold increase in the MIC values of gram-positive bacteria, 4 to 8 fold increase in the MIC values of gram-negative bacteria and 8 fold increase in the MIC value of $C$. albicans). Replacement of tryptophan by histidine (hLF S103) led to a peptide with reduced biological activity compared to hLF(1-11) with some MIC values of $50 \mu \mathrm{g} / \mathrm{mL}$ for C. albicans and of 25 or $50 \mu \mathrm{g} / \mathrm{mL}$ for gram-negative bacteria. The activity against gram-positive bacteria was also largely decreased with a MIC value of $6.3 \mu \mathrm{g} / \mathrm{mL}$ against MRSA compared to $1.6 \mu \mathrm{g} / \mathrm{mL}$ for $\mathrm{hLF}(1-11)$. Replacement of the tryptophan residue by tyrosine (hLF S104) also led to a decrease in the activity of the peptide against gram-positive bacteria, but this decrease was less significant than in the case of histidine (MIC values of 6.3, 3.1, 6.3 and $25 \mu \mathrm{g} / \mathrm{mL}$ against $S$. aureus, MRSA, S. epidermidis and S. mitis respectively, compared to $1.6,1.6,3.1$ and $6.3 \mu \mathrm{g} / \mathrm{mL}$ for $\mathrm{hLF}(1-11)$. The MIC values against gram-negative bacteria and yeasts were similar to the one obtained with hLF(1-11). Replacement of the tryptophan residue by phenylalanine (hLF S105) gave a peptide with biological activity similar to the one of hLF(1-11) with MIC values of $25 \mu \mathrm{g} / \mathrm{mL}$ for C. albicans and ranging from 1.6 to $12.5 \mu \mathrm{g} /$ $\mathrm{mL}$ for gram-positive bacteria and from 6.3 to $12.5 \mu \mathrm{g} / \mathrm{mL}$ for gramnegative bacteria.

For a better understanding of the role of the cysteine residue in the mechanism of action of hLF(1-11) against microorganisms, 3 other peptide analogues were synthesised. First, a peptide with a serine instead of the cysteine (position 10) was synthesised (hLF $\mathrm{N} 17$ ). This new peptide showed poor antimicrobial activity against yeasts, gram-positive and gram-negative bacteria, with the most optimal MIC value of $25 \mu \mathrm{g} / \mathrm{mL}$ for $S$. mitis. Next, we investigated the importance of the sulphur atom itself or the thiol residue was for their antimicrobial activity. For the latter, a peptide with a methylated cysteine was synthesised (hLF S 99). The resulting peptides showed a strong decrease in activity compared to that of hLF(1-11). A 4 fold decrease in the MIC value against MRSA and a 2 fold decrease in the MIC value against E. coli were observed. Against the other gram-positive and gram-negative bacteria tested, the MIC values were equal to $50 \mu \mathrm{g} / \mathrm{mL}$ and the MIC against $C$. albicans was $100 \mu \mathrm{g} / \mathrm{mL}$. Additionally, the disulphide version of this peptide of the $C$ amidated $h L F(1-11)$ was synthesised and its biological activity was similar to that of hLF(1-11) for yeasts (MIC value of $12.5 \mu \mathrm{g} / \mathrm{mL}$ against C. albicans compared to $12.5 \mu \mathrm{g} / \mathrm{mL}$ for hLF(1-11), gram-positive (MIC value of $3.1 \mu \mathrm{g} / \mathrm{mL}$ for MRSA compared to $1.6 \mu \mathrm{g} / \mathrm{mL}$ for $\mathrm{hLF}(1-11)$ ) and gram-negative bacteria (MIC value of $6.3 \mu \mathrm{g} / \mathrm{mL}$ against $E$. coli compared to $6.3 \mu \mathrm{g} / \mathrm{mL}$ for hLF(1-11)). These results confirmed the necessity of the cysteine residue for activity, either as a free cysteine, or as a cystine, which is the disulphide form of the cysteine.

Synthetic methods (manual or by automatic equipment) allow many peptides to be synthesized without problems. But during synthesis side reactions can always occur, such as incomplete deprotection or coupling reactions as the length of the peptide increases. We found during one of our synthesis processes a shifted peptide (WCA-GRRRSVQ; shifted on position 9) (hLF S63) and investigated the biological activity of those influence on the peptide. Furthermore, for bioimaging and bioengineering purposes, we tested the addition of a biotin (hLF S86), fluorescent moiety (hLF S87) and a so-called phishing peptide (hLF S43) for using in a convenient way to detect or immobilize these peptides. These kinds of modified peptides can be used for detection of biomarkers of immune mediated diseases. Biotin and Fluorescent can be added to the peptide as a capping group, or can be added to the side chain of a residue at the C-terminus of hLF. A Fluorescent group can de added during synthesis of the peptide. Representative results on the microbial activities towards different strains are given in Table $2 \mathrm{~A}$. Shifting of the amino acids showed a decrease of the antimicrobial activity towards all bacterial strains tested. In case of peptides hLF S43 and hLF S86 we found no difference in microbiological activity. Whereas peptide hLF S87 (fluorescent labelled) was showing slightly decreased activity only to the Streptococcus strains.

\section{Antifungal activities of hLF(1-11) peptide and the combination of this peptide with current antifungal agents}

Preliminary in vitro experiments indicated that the hLF(111) peptide is fungicidal against various C. albicans, Cryptococcus and Saccharomyces strains. Combinations of this peptide with fluconazole and amphotericin $\mathrm{B}$, were more effective than these antifungal or the peptide alone (Table 4). In vitro killing assays revealed that 1) the $\mathrm{hLF}(1-11)$ peptide was effective against fluconazole-resistant C. albicans as well as several other albicans and non-albicans strains, similar to what is reported by Lupetti $[28,51$ 53] and 2) a synergistic effect of fluconazole and hLF(1-11) peptide against various Candida species was showed. Results revealed that maximum killing effect was reached when treatment was started first by adding the peptide and later the addition of antifungal agents. Starting with the antifungal agent or combinations with the peptide showed higher outgrowth of the cells. When adding a second dose after $2 \mathrm{hrs}$ of incubation, the numbers of surviving cells after 24 hours were decreased in comparing to those cells without receiving a second treatment or those receiving a second dose after 5 minutes (Table 5). 
Table 4: Effect of combination of peptides with two standard antifungal drugs.

\begin{tabular}{|c|c|c|c|c|}
\hline \multicolumn{5}{|c|}{ FIC value } \\
\hline \multirow[t]{2}{*}{ Strain } & \multicolumn{4}{|c|}{ Combination } \\
\hline & hLF(1-11) + FLU & & hLF(1-11) + AMB & \\
\hline C. albicans Y01-19 & 0.5 & Synergy & 0.4 & Synergy \\
\hline C. albicans $A A$ (LUMC) & 0.3 & Synergy & 0.6 & Synergy \\
\hline C. albicans ATCC 10231 & 0.5 & Synergy & 0.7 & Synergy \\
\hline C. albicans ATCC 90028 & 0.5 & Synergy & 0.6 & Synergy \\
\hline C. albicans CMC 1968 (Perugia) & 2.0 & No interaction & ND & \\
\hline C. parapsilosis (LUMC) & 0.7 & Synergy & 0.8 & Synergy \\
\hline C. parapsilosis ATCC 22019 & 0.6 & Synergy & 0.6 & Synergy \\
\hline C. krusei (LUMC) & 0.4 & Synergy & 0.6 & Synergy \\
\hline C. glabrata (LUMC) & 0.3 & Synergy & 0.3 & Synergy \\
\hline C. tropicalis (LUMC) & 0.4 & Synergy & 0.7 & Synergy \\
\hline C. tropicalis CMC 2041 (Perugia) & ND & & 1.0 & Synergy \\
\hline Crypt. Neoformans WT (UMC) & 0.7 & Synergy & 0.5 & Synergy \\
\hline Crypt. Neoformans SKN7 (UMC) & 0.5 & Synergy & 1.1 & No interaction \\
\hline accharomyces cerevisiae ATCC 2601 & 1.0 & No interaction & ND & \\
\hline
\end{tabular}

AMB: Amphoteracin B; FLU: Fluconazole; hLF(1-11): Human Lactoferrin 1-11; ND: No Data. No interaction includes both indifference and additivity.

Interpretation; FIC values $<1=$ Synergism, 1-2 No interaction and $>2=$ Antagonism. ND $=$ not done

Table 5: Contributions of $\mathrm{hLF}(1-11)$ and fluconazole to the synergitic activity against fluconazole resistant Candida albicans . $^{2}$

\begin{tabular}{|c|c|c|c|c|}
\hline \multicolumn{5}{|c|}{ Time Kill } \\
\hline \multirow{2}{*}{ Compound / Dose } & \multirow{2}{*}{ Additional treatment } & \multirow{2}{*}{ Incubation time $^{c}$} & \multicolumn{2}{|c|}{ No. of surviving cells ${ }^{b}$} \\
\hline & & & $6 \mathrm{hr}$ & $24 \mathrm{hr}$ \\
\hline Saline & none & direct & $1 \times 10^{6}$ & $2 \times 10^{6}$ \\
\hline $\mathrm{hLF}(1-11) 50 \mu \mathrm{g}$ & none & direct & $2 \times 10^{4}$ & $2 \times 10^{5}$ \\
\hline $\mathrm{hLF}(1-11) 50 \mu \mathrm{g}$ & FLU $200 \mu \mathrm{g}$ & $5 \mathrm{~min}$ & $5.3 \times 10^{2 \mathrm{~d}}$ & $2 \times 10^{4 d}$ \\
\hline $\mathrm{hLF}(1-11) 50 \mu \mathrm{g}+\mathrm{FLU} 200 \mu \mathrm{g}$ & FLU $200 \mu \mathrm{g}$ & $2 \mathrm{hr}$ & $4 \times 10^{2 \mathrm{e}}$ & $6.2 \times 10^{3 \mathrm{e}}$ \\
\hline FLU $200 \mu \mathrm{g}$ & none & direct & $1 \times 10^{6}$ & $2 \times 10^{6}$ \\
\hline 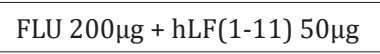 & none & direct & $8.3 \times 10^{4}$ & $1.9 \times 10^{5}$ \\
\hline FLU $200 \mu \mathrm{g}+\mathrm{hLF}(1-11) 50 \mu \mathrm{g}$ & $\mathrm{hLF}(1-11) 50 \mu \mathrm{g}$ & $2 \mathrm{hr}$ & $8.5 \times 10^{3}$ & $4.4 \times 10^{4}$ \\
\hline $\operatorname{hLF}(1-11) 12.5 \mu \mathrm{g}$ & none & direct & $5.4 \times 10^{4}$ & $2 \times 10^{5}$ \\
\hline $\operatorname{hLF}(1-11) 12.5 \mu \mathrm{g}$ & FLU $200 \mu \mathrm{g}$ & $5 \mathrm{~min}$ & $3.2 \times 10^{3 \mathrm{~d}}$ & $2 \times 10^{5 \mathrm{~d}}$ \\
\hline $\mathrm{hLF}(1-11) 12.5 \mu \mathrm{g}+\mathrm{FLU} 200 \mu \mathrm{g}$ & FLU $200 \mu \mathrm{g}$ & $2 \mathrm{hr}$ & $3.8 \times 10^{3 \mathrm{e}}$ & $3.3 \times 10^{4 \mathrm{e}}$ \\
\hline FLU $200 \mu \mathrm{g}$ & none & direct & $1 \times 10^{6}$ & $2 \times 10^{6}$ \\
\hline FLU $200 \mu \mathrm{g}+\mathrm{hLF}(1-11) 12.5 \mu \mathrm{g}$ & none & direct & $5.2 \times 10^{4}$ & $2.3 \times 10^{5}$ \\
\hline FLU $200 \mu \mathrm{g}+\mathrm{hLF}(1-11) 12.5 \mu \mathrm{g}$ & hLF(1-11) $12.5 \mu \mathrm{g}$ & $2 \mathrm{hr}$ & $3.3 \times 10^{4}$ & $9.8 \times 10^{4}$ \\
\hline
\end{tabular}

${ }^{a} 10^{6} \mathrm{CFU}$ of Candida cells $/ \mathrm{ml}$ were incubated with dose $\mathrm{hLF}(1-11)$ or $/$ and $200 \mu \mathrm{g}$ fluconazole $/ \mathrm{ml}$ and incubated for $6-24 \mathrm{~h}$ at $37{ }^{\circ} \mathrm{C}$. Additional treatment were respectively $5 \mathrm{~min}$ or $2 \mathrm{hr}$ later added and incubated for 6 and $24 \mathrm{~h}$.

${ }^{\mathrm{b}} \mathrm{Data}$ are means from at least three independent experiments, here representative single data are given rather than a range for clarity and ease of comparison of peptide efficacy. The MIC of fluconazole-resistant C. albicans are $>256 \mu \mathrm{g} / \mathrm{ml}$.

'Time of additional treatment after incubation of compounds

${ }^{\mathrm{d} S i g n i f i c a n t l y ~ d i f f e r e n t}(\mathrm{P}<0.05)$ from values obtained with Candida cells exposed to $\mathrm{hLF}(1-11)$ alone

eSignificantly different $(\mathrm{P}<0.05)$ from values obtained with Candida cells exposed to combination of hLF $(1-11)$ and fluconazole; FLU = fluconazole 


\section{In vivo Experiments}

\section{Therapeutic efficacy}

Our results revealed that compared to the control experiments hLF(1-11) was effective $(\mathrm{P}<0.05)$ against disseminated $C$. albicans infections from $0.004 \mathrm{ng}$ of $\mathrm{hLF}(1-11) / \mathrm{kg}$ body weight on and its antifungal activity levelled off after $0.4 \mu \mathrm{g}$ of hLF(1-11)/kg body weight; the maximal antifungal effect amounted to reduction (Figure 3). As expected, the control peptide and fluconazole were without effect and $40 \mu \mathrm{g}$ of $\mathrm{hLF}(1-11) / \mathrm{kg}$ body weight and the optimal dose of $0.5 \mu \mathrm{g} / \mathrm{kg}$ amphotericin B were equally effective. Second; efficacy of multiple daily i.v. injection of hLF(1-11), The results revealed that the antifungal activity of hLF(1-11) could already be followed at $4 \mathrm{~h}$ after treatment e.g. CFU C. albicans in mice treated with $40 \mu \mathrm{g}$ of $\mathrm{hLF}(1-11) / \mathrm{kg}$ body weight amounted to $1.9 \times 10^{5} \mathrm{CFU} / \mathrm{g}$ kidney and control animals to $8.6 \times 10^{6} \mathrm{CFU} / \mathrm{g}$ kidney ( $\mathrm{n}=5$ mice; $\mathrm{P}<0.05$ ) (Figure 4$)$. All inadequately treated mice displayed clinical symptoms, such as fever and ruffed fur, $27 \%$ of these mice died on the second day of infection.

Figure 3: Effect of dose hLF(1-11) against fluconazole-resistant Candida

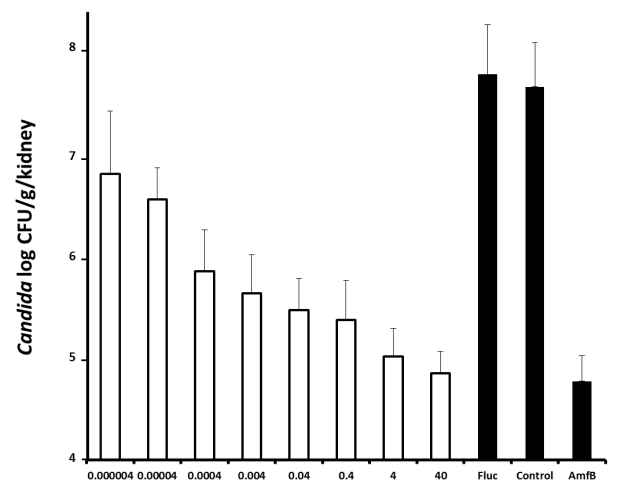

Dose hLF(1-11) ( $\mu \mathrm{g} / \mathrm{kg}$ bodyweight)

Figure 3: Efficacy of a single i.v. injection with different doses of $h L F(1-11) 24$ hours after infection. Antifungal activity of hLF(111) against a disseminated infection with fluconazole resistant $C$. albicans in neutropenic mice. Mice were rendered neutropenic by i.p. injection of $100 \mathrm{mg}$ of cyclophosphamide/ $\mathrm{kg}$ at days -3 and 0 of the infection. Next, mice were intravenously infected with $1 \times 10^{5} \mathrm{CFU}$ fluconazole-resistant C. albicans in $0.1 \mathrm{ml}$ of saline and $24 \mathrm{~h}$ later saline containing various amounts (range: $0.04 \mathrm{ng} /$

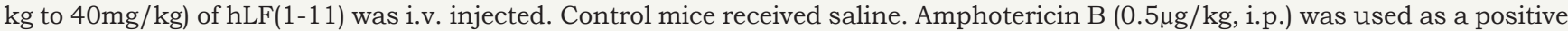
control and fluconazole dissolved in saline $(5 \mathrm{mg} / \mathrm{kg}$, subcutaneously) was used as negative control. After $18 \mathrm{~h}$ of treatment the mice were sacrificed and the kidneys removed, weighed, and homogenized and the number of viable yeasts was determined microbiologically. Values and the medians are given. The results are from 3-4 independent experiments.

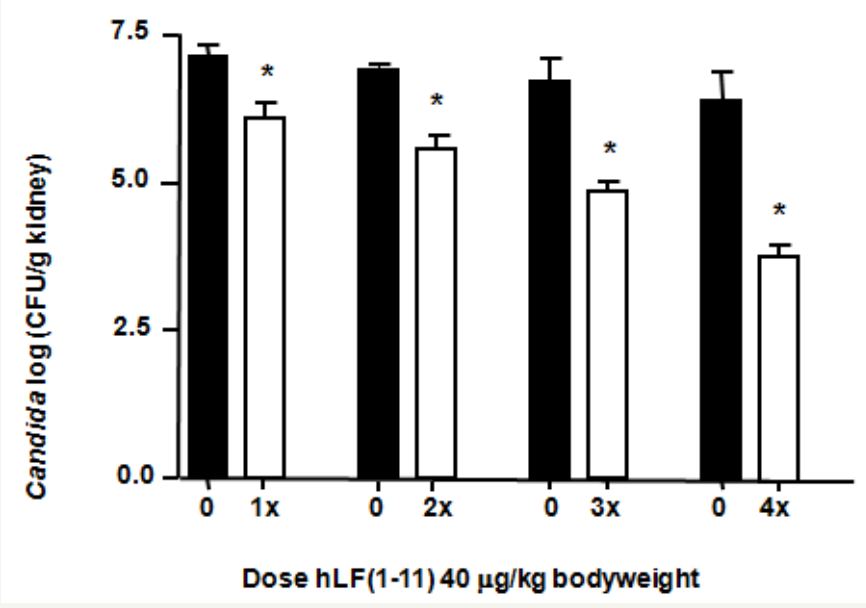

Figure 4: Efficacy of multiple daily i.v. injection of $h L F(1-11)$, starting 4 hours after infection. Antifungal activity of hLF(1-11) against a disseminated infection with fluconazole-resistant $C$. albicans in neutropenic mice. Mice were rendered neutropenic by i.p. injection of $100 \mathrm{mg}$ of cyclophosphamide/ $\mathrm{kg}$ at days -3 and 0 of the infection. Next, mice were intravenously infected with $1 \times 10^{5} \mathrm{CFU}$ fluconazole-resistant C. albicans in $0.1 \mathrm{ml}$ of saline. As indicated, on subsequent day's groups of animals received either another, two or more injections. At $24 \mathrm{~h}$ after the last injection of the peptide mice were sacrificed and the kidneys removed, weighed, and homogenized and the number of viable yeasts was determined microbiologically. Values and the medians are given. The results are from 3-4 independent experiments. 
Third; the efficacy of hLF(1-11) in cyclophosphamide, cyclosporine or hydrocortisone treated mice. Finding that, persistently immune suppressed treatment with repeated doses of cyclophosphamide, cyclosporine, hydrocortisone and a combination of two former compounds did not showed differences in antifungal activity against Candida albicans with $0.4 \mu \mathrm{g}$ of hLF(111)/kg body weight in mice, indicating, that this treatment has no or little effect on the efficacy of the peptides (Figure 5).

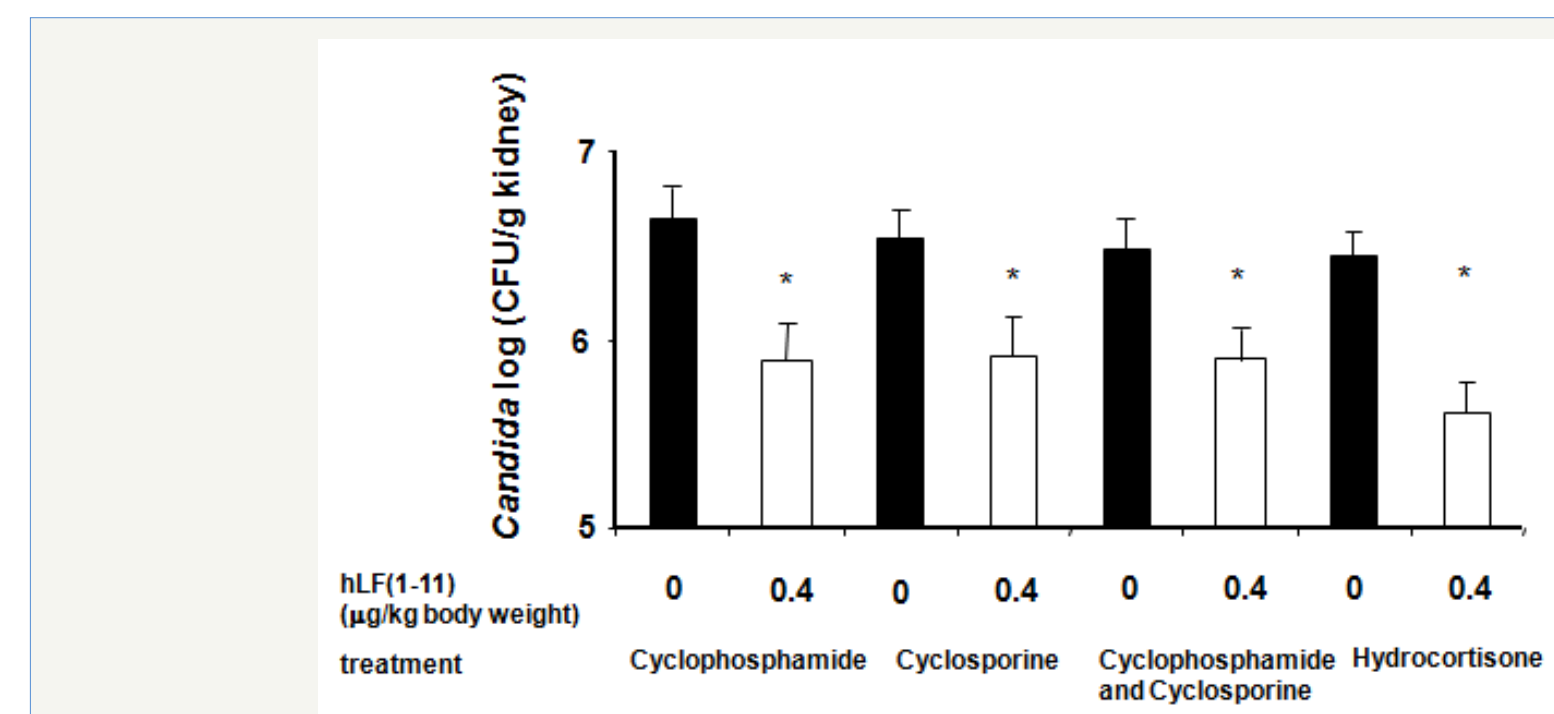

Figure 5: Efficacy of $\mathrm{hLF}(1-11)$ in Cyclophosphamide, cyclosporine or hydrocortisone treated mice. The study compromised eight groups of mice. At day -3 and day 0 the animals received intraperitoneal a dose of (A) $100 \mathrm{mg} / \mathrm{kg}$ cyclophosphamide, (B) subcutaneously a dose of $20 \mathrm{mg} / \mathrm{kg}$ cyclosporine, (C) or a combination of cyclophosphamide and cyclosporine and (D) groups received intraperitoneal a dose of $25 \mathrm{mg} / \mathrm{kg}$ hydrocortisone. At day 0, 4 hours after administration of the second dose immunosuppressive, all groups received Candida albicans by an intravenous injection. 20h later saline containing $\mathrm{hLF}(1-$ 11) $(0.4 \mu \mathrm{g} / \mathrm{kg})$ was i.v injected. After $24 \mathrm{~h}$ of treatment the mice were sacrificed and the kidneys removed, weighed, and homogenized and the number of viable yeasts was determined microbiologically. Values and the medians are given. The results are from 3-4 independent experiments.

\section{Prophylactic efficacy}

To determine if the efficacy of a single dose of hLF(1-11) based on patent dose of $100-400 \mathrm{mg} / \mathrm{kg} /$ day for Candida infections on different time points before and after infection were determined in mice. The results revealed that the hLF(1-11) peptide is effective against an infection with Candida albicans when given $48 \mathrm{~h}$ before or $24 \mathrm{~h}$ after infection indicating that the single administration of the peptide may be given prophylactic as well as therapeutically (Figure 6).

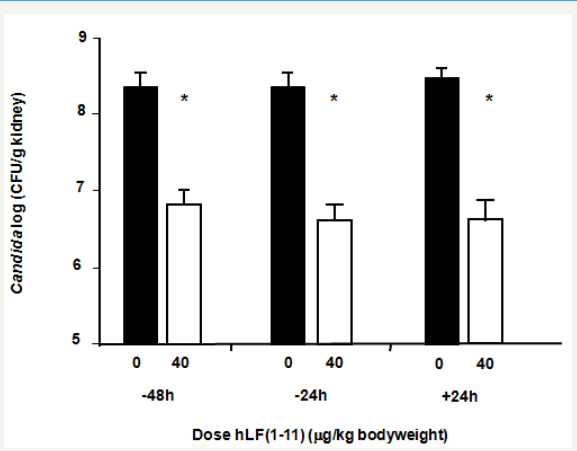

Figure 6: Efficacy of single dose of $h \mathrm{LF}(1-11)$ on different time points before and after infection. Mice (immunocompromised by two injections of $100 \mathrm{mg}$ cyclophosphamide on day -3 and day 0 of the infection) were injected intravenously with $1 \times 10^{5} \mathrm{CFU}$ Candida albicans; strain YO1-19 in the tail, Experiment started at $48 \mathrm{hr}$ before till $24 \mathrm{hr}$ after infection of Candida to observe the prophylaxes of the compounds. On day 0 an i.v. injection of the placebo in the tail vein was given. 48 hours thereafter mice were sacrificed, blood collected by heart puncture and the kidneys removed. Plasma was prepared from blood samples and stored at $-80^{\circ} \pm 10^{\circ} \mathrm{C}$ for possible future analysis. The kidneys were homogenized using an ultra-turrax $\AA$ and dilutions of the homogenate prepared in saline. Limiting dilutions were plated onto agar plates and two days later the number of CFU are determined as a measure of viable Candida albicans for each individual mouse. As a measure of in vivo antifungal activity CFU reduction of $>90 \%$ (1 log reduction) in comparison to the negative control (vehicle only) was taken. Values and the medians are given. The results are from 3-4 independent experiments. 
A

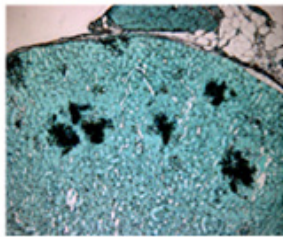

C

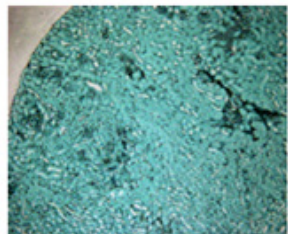

B

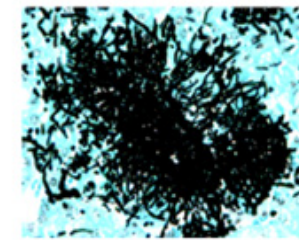

D

Figure 7: Infectious foci in kidneys of neutropenic mice with an invasive Candida albicans infection. Cyclophosphamide-treated Swiss outbred mice were intravenously infected with $1 \times 10^{5} \mathrm{CFU}$ fluconazole-resistant Candida albicans and $24 \mathrm{~h}$ thereafter treated intravenously with $40 \mu \mathrm{g}$ of $\mathrm{hLF}(1-11) / \mathrm{kg}$ body weight $(\mathrm{C}, \mathrm{D})$ or not $(\mathrm{A}, \mathrm{B})$. Eighteen hours thereafter mice were sacrificed and kidneys were removed, fixed and embedded in paraffin wax. Next, $5-\mu \mathrm{m}$ sections were cut and stained with Grocott's modification of Gomori's methamine-silver stain and counterstained with light green. Magnification 50x(A,C) and 400x (B,D) show treated and non-treated kidneys in the figure.

Microscopical examination of Grocott-stained kidney tissue sections of mice with a disseminated fluconazole-resistant $C$. albicans infection revealed that the size and number of infectious foci decreased with doses of hLF(1-11) of $40 \mu \mathrm{g} / \mathrm{kg}$ (Figure $7 \mathrm{~A}$ \& 7B) as compared to untreated animals (Figure 7C \& 7D). In addition, the morphology of $C$. albicans in these tissue sections was studied. The results revealed that $C$. albicans cells, which were mainly filamentous in the foci in untreated animals (Figure 7D), were growing as blastoconidia in mice effectively treated with this peptide (Figure 7B).

\section{Synergistic efficacy (antifungal)}

The synergistic effect of low dose of $0,004 \mu \mathrm{g}$ hF(1-11) kg/ body weight and different doses fluconazole $(50-200 \mathrm{mg} / \mathrm{kg} /$ body weight) was determined against fluconazole resistant Candida and fluconazole sensitive Candida strains. The results revealed that for fluconazole resistant Candida maximum effect was reached by dose of $200 \mathrm{mg} / \mathrm{kg}$ fluconazole and lower doses of fluconazole without effect (Figure 8). For fluconazole sensitive Candida, effect of $0,004 \mu \mathrm{g} / \mathrm{kg} /$ body weight $\mathrm{hLF}(1-11)$ in combination with fluconazole was already calculated with a dose of $50 \mathrm{mg} / \mathrm{kg}$ fluconazole (Figure 9).

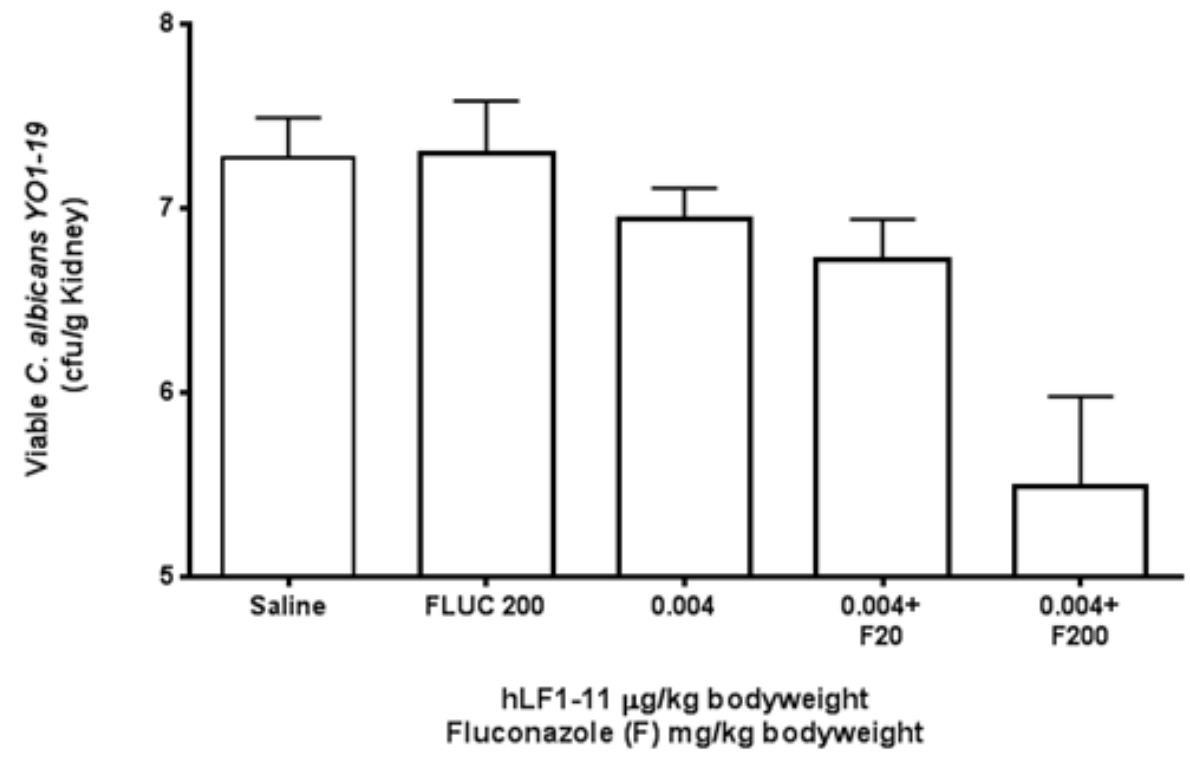

Figure 8: Synergistic effect of low dose $\mathrm{hlF}(1-11)$ against fluconazole-resistant Candida albicans YO1-19. Antifungal activity of hLF(1-11) in combination with fluconazole against a disseminated infection with fluconazole resistant $C$. albicans in neutropenic mice. Mice were rendered neutropenic by i.p. injection of $100 \mathrm{mg}$ of cyclophosphamide/kg at days -3 and 0 of the infection. Next, mice were intravenously infected with $1 \times 10^{5} \mathrm{CFU}$ fluconazole-resistant C. albicans in $0.1 \mathrm{ml}$ of saline. $24 \mathrm{~h}$ later saline containing $0.004 \mu \mathrm{g} / \mathrm{kg}$ of $\mathrm{hLF}(1-11)$ was i.v. injected. Fluconazole, dissolved into saline (subcutaneously injected) was used as negative control and to show synergism. After $18 \mathrm{~h}$ of treatment the mice were sacrificed and the kidneys removed, weighed, and homogenized and the number of viable yeasts was determined microbiologically. Values and the medians are given. The results are from 4 independent experiments. Each dot represented the mean value of an independent experiment. 


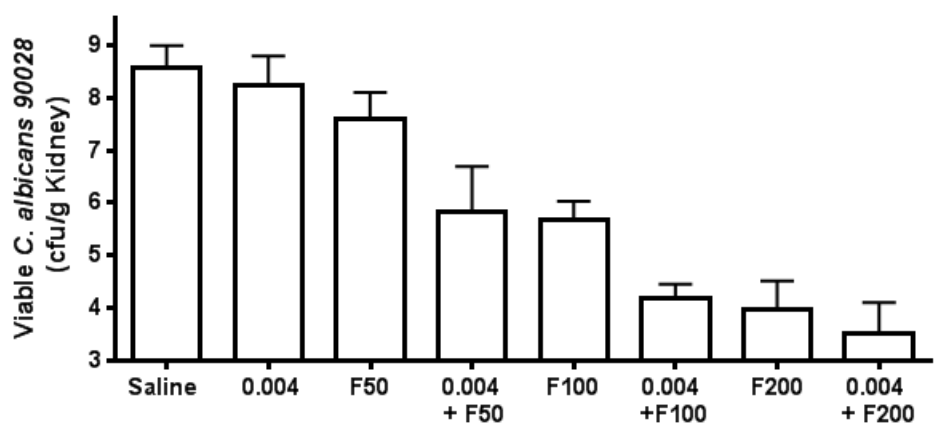

hLF $0.004 \mu \mathrm{g} / \mathrm{kg}$ bodyweight

Fluconazole (F) mg/kg bodyweight

Figure 9: Synergistic effect of low dose hlF(1-11) aganist fluconazole-sensitive Candida albicans 90028. Antifungal activity of hLF(1-11) in combination with fluconazole against a disseminated infection with fluconazole sensitive $C$. albicans in neutropenic mice. Mice were rendered neutropenic by i.p. injection of $100 \mathrm{mg}$ of cyclophosphamide/ $\mathrm{kg}$ at days -3 and 0 of the infection. Next, mice were intravenously infected with $1 \times 10^{5} \mathrm{CFU}$ fluconazole-sensitive C. albicans in $0.1 \mathrm{ml}$ of saline. $24 \mathrm{~h}$ later saline containing $0.004 \mu \mathrm{g} / \mathrm{kg}$ of hLF(1-11) was i.v. injected. Various amounts of fluconazole, dissolved into saline (subcutaneously injected) were used to show synergism. After $18 \mathrm{~h}$ of treatment the mice were sacrificed and the kidneys removed, weighed, and homogenized and the number of viable yeasts was determined microbiologically. Values and the medians are given. The results are from 5 independent experiments. Each dot represented the mean value of an independent experiment.

Moreover, efficacy of hLF(1-11) in combination with fluconazole against fluconazole-resistant systemic candidiasis; results revealed that $h L F(1-11)$ and fluconazole combination was statistically different $(\mathrm{P}<0.01)$ against both single treated $\mathrm{hLF}(1-11)$ and fluconazole groups (ANOVA). In vitro and in vivo data suggests that $\mathrm{hLF}(1-11)$ at low concentrations of $0,004 \mu \mathrm{g} / \mathrm{kg} /$ body weight is more effective in combination with conventional antifungal than alone.

The data presented in this study suggests that combination therapy of hLF(1-11) and fluconazole may be used to enhance fluconazole sensitivity in resistant as well as in sensitive strains.

\section{Synergistic efficacy (antibacterial)}

Our results revealed that compared to the control peptide hLF(1-11) was effective $(\mathrm{P}<0.05)$ against disseminated $M R S A$ 2141 infections from $0,004 \mu$ g of hLF(1-11)/kg body weight on and its antibacterial activity levelled off after $0.4 \mu \mathrm{g}$ of hLF(1-11)/ $\mathrm{kg}$ body weight. As expected, the control peptide were without effect and 0,004 $\mu \mathrm{g}$ of hLF(1-11) and the optimal dose of $0.0625 \mathrm{mg}$ vancomycin/ kg body weight were equally effective. The efficacy of hLF(1-11) with vancomycin showed that maximum effect was reached by the low dose. Higher doses of hLF(1-11) were without additional effect (Figure 10).

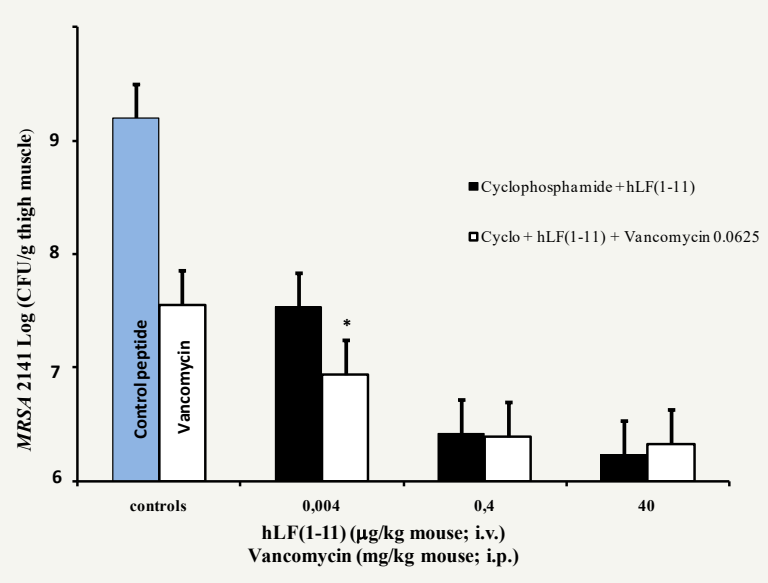

Figure 10: Synergistic effect of $\mathrm{hlF}(1-11)$ with Vancomycin in immune comprised mice with MRSA 2141 (thigh muscle infection). Antibacterial activity of $\mathrm{hLF}(1-11)$ against a disseminated infection with MRSA 2141 in neutropenic mice. Mice were rendered neutropenic by i.p. injection of $100 \mathrm{mg}$ of cyclophosphamide/ $\mathrm{kg}$ at days -3 and 0 of the infection. Next, mice were intramuscular infected with $2 \times 10^{7} \mathrm{CFU}$ MRSA 2141 in $0.1 \mathrm{ml}$ of saline and $24 \mathrm{~h}$ later saline containing various amounts (range: $0.004 \mu \mathrm{g} / \mathrm{kg}$ to $40 \mu \mathrm{g} / \mathrm{kg})$ of $\mathrm{hLF}(1-11)$ was i.v. injected. Control mice received scrambled peptide. Vancomycin $(0.0625 \mathrm{mg} / \mathrm{kg}$, i.p.) was used as a positive control and used to show synergism. After $18 \mathrm{~h}$ of treatment the mice were sacrificed and the thigh muscles removed, weighed, and homogenized and the number of viable yeasts was determined microbiologically. Values and the medians are given. The results are from 3-4 independent experiments. 


\section{Supporting Information}

\section{Haemolytic effect}

As described previously [26,54], freshly collected heparinsupplemented blood from sheep's was centrifuged for $15 \mathrm{~min}$. at $100 \mathrm{~g}$ to remove the buffy coat. The erythrocytes were washed three times with PBS, centrifuged for $10 \mathrm{~min}$. at $1000 \mathrm{~g}$, and suspended in PBS to $1 \%$ (vol/vol). Compounds were serially diluted in PBS and $100 \mu \mathrm{l}$ were added in triplicate to $100 \mu \mathrm{l}$ of the erythrocyte suspension (final concentration $6-200 \mu \mathrm{g} / \mathrm{mL}$ ), incubated for $1 \mathrm{~h}$ at $37{ }^{\circ} \mathrm{C}$ and then centrifuged for 5 minutes at $1000 \mathrm{~g}$. PBS and $1 \%$ Tween-20 were used to establish 0 and $100 \%$ haemolysis. Of the supernatants $150 \mu \mathrm{l}$ were transferred to a flat-bottom 96-well plate, and haemoglobin release were determined by light absorbance at $450 \mathrm{~nm}$. This was also macroscopically visible by orangediscoloration of the samples. The percentages of intact erythrocytes were calculated:

(1 - $\left(\mathrm{A}_{450}\right.$ Peptide $\left.-\mathrm{A}_{450} \mathrm{PBS}\right) /\left(\mathrm{A}_{450}\right.$ Tween $\left.\left.-\mathrm{A}_{450} \mathrm{PBS}\right)\right) \times 100 \%$.

hLF(1-11), solved into a Phosphate buffered solution (PBS) did not cause haemolysis at concentration up to $2000 \mu \mathrm{g} / \mathrm{mL}$. Only higher concentrations of $\mathrm{hLF}(1-11)(>2500 \mu \mathrm{g} / \mathrm{mL})$ resulted in significant haemolysis (37\%). This was also macroscopically visible by orange-discoloration of the samples.

\section{Discussion}

In this study, the importance of the different a residues ofhLF(1-11) for biological activity was investigated. Various peptides have been synthesised and tested for biological activity against various strains of yeasts, gram-positive and gram-negative bacteria. $N$ acetylation of the peptide led to an almost unchanged activity against gram-positive bacteria (MIC value of 1 step) while the activity against yeast and gram-negative bacteria stayed unchanged. On the contrary, C amidation did not have any effect on the activity against gram-positive bacteria and yeasts but slightly improved the biological activity of the peptide against gramnegative bacteria. This has for consequence that the peptide with free $N$ - and $C$ - termini is more selective for gram-positive bacteria. Protection of both the $N$ - and the $C$-termini reduces this selectivity.

Positive charges residues are necessary for the biological activity of the peptide against the bacteria as well as against yeasts $[10,55]$. Indeed, replacement of the 4 arginine residues (position 2,3,4, and 5) by citrullin showed a peptide without any killing activity, even against yeasts. Moreover, the activity of the peptide was reduced when one of the arginine residues was replaced by alanine. Replacement showed the importance of these positively charged residues for biological activity [56-59]. Glycine replacement by alanine led to a peptide with similar biological activity. This is coherent with the results from Nibbering et al. [60] who pointed out the possibility of removing the glycine residue without loss of biological activity. The activity of AMPs against bacteria is generally attributed to their amphipathic residues. Indeed, bacteria are negatively charged because of the presence of phospholipids on their outer membrane. Thus, the mechanism of action of AMPs starts by electrostatic attractions between the positively charged AMPs and negatively charged bacteria. On the contrary, yeasts have an amphiphilic outer membrane. The mechanism of antifungal activity is more complex and often involves entry of the peptide into the cell or act via a number of different mechanisms such as induction of signalling cascades, interaction with intracellular targets or membrane permeabilization [26]. In the case of hLF(111 , reducing the number of positive charges reduces the activity of the peptide against bacteria. This is coherent with the accepted knowledge that AMPs need to be positively charged to attach to the negatively charged bacterial cell wall. However, the activity of hLF(1-11) against yeasts is also reduced when the number of positive charges is reduced. This can be attributed to a cluster of charge interaction or transmembrane passage [53], but in the present study we did not investigated these options. The tryptophan residues as well as the cysteine residues were both very important for the activity of the peptide. Replacement of the tryptophan residue (position 9) by alanine led to a remarkable decrease in biological activity similar as observations in other studies [56-58].

To understand the role of the tryptophan residue $[61,62]$ in the mechanism of action of hLF(1-11), this residue was replaced by other hydrophobic aromatic residues (trans membrane passage), which are either by histidine, by tyrosine or by phenylalanine. Substitution of tryptophan residues may generate a potent peptide with improved antimicrobial activity. Salt resistance could make the peptide more efficient in destabilization and / or insertion membranes but has to be investigated.

In another part of the study we have shown that the tryptophan residue can be replaced by phenylalanine without loss of activity and by tyrosine with only a slight loss in activity. As a consequence from our data, a hydrophobic aromatic residue is necessary for activity of the peptide against yeasts, gram-positive, and gramnegative bacteria. Indicating that after interaction of the peptide with the phospholipids head of the bilayer, the hydrophobic residue is necessary for the insertion into the bilayer [33].

Furthermore, we have shown in this study that the cysteine residue (position 10), either as a cysteine or in is oxidised form which is a cystine residue, is also necessary for biological activity against all the species tested. Our results show the importance of the cysteine residue in the peptide sequence [63]. In the cells, cysteine can be oxidised to cystine and cystine can be reduced to cysteine. In similar way, the peptide containing cysteine can be oxidised and reduced in the cell as well. If the peptide is involved in a redox process that would explain that hLF(1-11) as well as its dimer have both the same activity against microorganisms.

Finally, for mimicking patient studies and to measure a direct effect of the peptide without involvement of the host immune cells; antifungal activity hLF(1-11) is highly effective against (fluconazole-resistant) C. albicans infections in neutropenic 
mice as was observed for earlier studies with MRSA and Candida infected mice $[28,29,64]$. This conclusion is based on the following observations. First, our results for therapeutic efficacy: results revealed that the survival / outgrowth of mice treated with hLF(111) was significantly lower $(1,5 \mathrm{Log})$ compared to the untreated controls. Second, we found increased effects of killing when hLF(111) was injected in combination with fluconazole $(p<0.05)$.

Third, the hLF(1-11) peptide was as effective against Candida infections in cyclophosphamide-treated, cyclosporine-treated, and hydrocortisone-treated mice, indicating that the peptide is effective in immunocompromised animals. The possibility that hLF(1-11) exerts its antifungal actions - in part - by stimulating the recovery of leukocytes in immunocompromised mice can be excluded, since we found no effect of the peptide on the numbers of leukocyte (sub)populations in these animals as we observed earlier (data not shown) [43]. Our finding that hLF(1-11) is effective against an infection with Candida when given $48 \mathrm{~h}$ before the infection implicates that this peptide may also be used prophylactically. Since the pharmacological serum half-life of this peptide in the circulation is short $(<20 \mathrm{~min})$ [32], it is unlikely that sufficient amounts of the peptide remain present in the serum during the $48 \mathrm{~h}$ interval between injection of the hLF(1-11) peptide and the infectious agent. However, the tissue half-life of the peptide may be considerably longer than its serum half-life and thus after $48 \mathrm{~h}$ the tissue-bound hLF(1-11) could be responsible for the observed reduction in fungal counts in kidney [29]. Another explanation for the prophylactic effect involves priming of immune cells for enhanced antimicrobial functions by hLF(1-11), as has been reported for the IDR-1 peptide [65]. Since the hLF(1-11) peptide is also effective against infections in neutropenic mice (this study) and [43] most likely neutrophils are less crucial for the anti-infective actions of the peptide.

\section{Concluding Remarks}

Despite the good in vitro activities of traditional antifungal, therapy is often partially effective and relapses may occur during the course of the disease. For this reason, new strategies based on novel molecular targeting agents are warranted to further improve the long-term outcome of fluconazole resistant Candida infection treatment. Accordingly to this study, it is useful to investigate the therapeutic strategy of combining clinically used antifungal with peptides against pathogens. Earlier studies demonstrated that combination therapies merit further development as potential novel treatments of (multi) resistant microorganisms (e.g. bacteria and fungi) [64-69]. Many peptides are currently in clinical development, but most of these are only intended for topical use due there direct result in toxicity. The hLF(1-11) peptide did not cause haemolysis in phosphate buffered solutions at concentration up to $2.000 \mu \mathrm{g} / \mathrm{mL}$. This is coherent with the results from Stallman et al. [70]. Results indicate that salt concentration can markedly influence the haemolysis, similar to what is reported for other peptides [71] (Figure 2). Safety of hLF(1-11) is already evaluated in different studies [32,72], and showed a strategy to use such peptides to prevent and treat opportunistic infections.

\section{Acknowledgment, funding and conflict of interest (commercial activity or affiliations)}

The authors want to thank Dr. Matteo Bassetti and Dr. Carlo Tascini for providing the clinical strains used in Perugia; LR was supported temporary researcher with a grant from Fondazione Cassa di Risparmio di Perugia; DCP was supported by a PhD program of the Biotechnology Doctorate at the University of Perugia.

\section{Conflict of Interest}

$\mathrm{CB}$ and MR are founders, board members, and shareholders of CBMR Scientific Inc., Suite 161, 2057-111 Street NW, Edmonton, Alberta, Canada. The other authors declare that they have no competing interests.

\section{References}

1. Magill SS, Edwards JR, Bamberg W (2014) Multistate point-prevalence survey of health care-associated infections. N Engl J Med 370(13): 11981208.

2. CDC- Antibiotic Resistance Threats in the United States, 2013: Flucanozole-Resistant Candida.

3. Fung-Tomc JC, White TC, Minassian B, Huczko E, Bonner DP (1999) In vitro antifungal activity of BMS-207147 and itraconazole against yeast strains that are non-susceptible to fluconazole. Diagn Microbiol Infect Dis 35(2): 163-167.

4. Ghannoum MA, Louis BR (1999) antifungal agents: mode of action, mechanisms of resistance, and correlation of these mechanisms with bacterial resistance. Clin Microbiol Rev 12(4): 501-517.

5. Graybill JR (2000) The role of murine models in the development of antifungal therapy for systemic mycoses. Drug Resist Update 3(6): 364383.

6. Vallabhaneni S, Cleveland A, Farley M, Harrison LH, Schaffner W et al. (2015) epidemiology and risk factors for echinocandin nonsusceptible candida glabrata bloodstream infections: data from a large multisite population-based candidemia surveillance program, 2008-2014. Open Forum Infect Dis 2(4): ofv163.

7. Lockhart SR, Iqbal N, Cleveland AA, Farley MM, Harrison LH, et al. (2012) Species identification and antifungal susceptibility testing of Candida bloodstream isolates from population-based surveillance studies in two US cities from 2008 to 2011. J Clin Microbiol 50(11): 3435-3442.

8. Perez EE, Orange JS, Bonilla F, Chinen J, Chinn IK, et al. (2017) Update on the use of immunoglobulin in human disease: A review of evidence. Journal of Allergy and Clinical Immunology 139(3S): S1-S46.

9. Freifeld AG, Bow EJ, Sepkowitz KA, Boeckh MJ, Ito JI, et al. (2011) Clinical practice guideline for the use of antimicrobial agents in neutropenic patients with cancer: 2010 update by the infectious diseases society of america. Clin Infect Dis 52(4): e56-e93.

10. Pappas PG, Kauffman CA, Andes DR, Clancy CJ, Marr KA, et al. (2016) Clinical practice guideline for the management of candidiasis: 2016 update by the infectious diseases society of america. Clin Infect Dis 62(4): e1-e50

11. Edmond MB, Wallace SE, McClish DK, Pfaller MA, Jones RN, et al. (1999) Nosocomial bloodstream infections in the United States hospitals: a three-year analysis. Clin Infect Dis 29(2): 239-244.

12. Pfaller MA, Diekema DJ, Jones RN, Jones RN, Sader HS, Fluit AC, et al. (2001) International surveillance of bloodstream infections due to Candida species: frequently of occurrence and in vitro susceptibilities to fluconazole, revuconazole, and voriconazole of isolates collected from 1997 through 1999 in the SENTRY antimicrobial surveillance program. J Clin Microbiol 39(9): 3254-3259. 
13. Morgan J, Meltzer MI, Plikaytis BD, Sofair AN, Huie-White S, et al (2005) Excess mortality, hospital stay, and cost due to candidemia: a case-control study using data from population-based candidemia surveillance. Infection control and hospital epidemiology. Infect Control Hosp Epidemiol 26(6): 540-547.

14. Ben-Ami R, Olshtain-Pops K, Krieger M, Oren I, Bishara J, et al. (2012) Antibiotic exposure as a risk factor for fluconazole-resistant Candida bloodstream infection. Antimicrob Agents Chemother 56(5): 25182523.

15. Datamonitor: Strategic Perspectives: Invasive Fungal Infections. Reference code DMHC 1855, Jan 2003.

16. Sanglard D, Odds FC (2002) Resistance of Candida species to antifungal agents: Molecular mechanisms and clinical consequences. Lancet Infect Dis 2(2): 73-85.

17. Kontoyiannis DP, Lewis RE (2002) Antifungal drug resistence of pathogenic fungi. Lancet 359(9312): 1135-1144.

18. Nekhotiaeva N, Elmquist A, Rajarao GK, Hallbrink M, Langel U, et al. (2004) Cell entry and antimicrobial properties of eukaryotic cellpenetrating peptides. FASEB J 18(2): 394-396.

19. Abi-Said D, Anaissie E, Uzun O, Raad I, Pinzcowski H, et al. (1997) The epidemiology of hematogenous candidiasis caused by different Candida species. Clin Infect Dis 24(6): 1122-1128.

20. McNeil MM, Nash SL, Hajjeh RA, Phelan MA, Conn LA, et al. (2001) Trends in mortality due to invasive mycotic diseases in the United States, 1980-1997. Clin Infect Dis 33(5): 641-647.

21. Hancock RE (2001) Cationic peptides: effectors in innate immunity and novel antimicrobials. Lancet Infect Dis 1(3): 156-164.

22. Hancock RE, Diamond G (2000) The role of cationic antimicrobial peptides in innate host defences. Trends Microbiol 8(9): 402-410.

23. Scott MG, Hancock RE (2000) Cationic antimicrobial peptides and their multifunctional role in the immune system. Crit Rev Immunol 20(5): 407-431.

24. Gudmundsson GH, Agerberth B (1999) Neutrophil antibacterial peptides, multifunctional effector molecules in the mammalian immune system. J Immunol Methods 232(1-2): 45-54.

25. Ganz T (2001) Chemistry. Rings of destruction. Nature 412(6845): 392393.

26. Helmerhorst EJ, Reijnders IM, van't HW, Veerman EC, Amerongen NAV (1999) A critical comparison of the hemolytic and fungicidal activities of cationic antimicrobial peptides. FEBS Letters 449(2-3): 105-110.

27. Farnaud S, Evans RW (2003) Lactoferrin-a multifunctional protein with antimicrobial properties. Molecular Immunology 40(7): 395-405.

28. Lupetti A, Paulusma-Annema A, Welling MM, Dogterom-Ballering $H$, Brouwer CP, et al. (2003) Synergistic activity of the N-terminal peptide of human lactoferrin and fluconazole against Candida species. Antimicrob Agents Chemother 47(1): 262-267.

29. Brouwer CPJM, Welling MM (2008) Various routes of administration of $99 \mathrm{mTc}$-labeled synthetic lactoferrin antimicrobial peptide hLF(111) enables monitoring and effective killing of multidrug-resistant Staphylococcus aureus infections in mice. Peptides 29(7): 1109-1117.

30. Kuwata H, Yip TT, Yip CL, Tomita M, Hutchens TW (1998) Bactericida domain of lactoferrin: detection, quantitation, and characterization of lactoferricin in serum by SELDI affinity mass spectrometry. Biochem Biophys Res Commun 245(3): 764-773.

31. Tomita M, Wakabayashi H, Shin K, Yamauchi K, Yaeshima T, et al. (2009) Twenty-five years of research on bovine lactoferrin applications. Biochimie 91(1): 52-57.

32. Velden WJ, van Iersel TM, Blijlevens NM, Donnelly JP (2009) Safety and tolerability of the antimicrobial peptide human lactoferrin hLF(1-11). BMC Med 7:44
33. Farrotti A, Bocchinfuso G, Palleschi A, Rosato N, Salnikov ES, et al. (2015) Molecular dynamics methods to predict peptide locations in membranes: LAH4 as a stringent test case. Biochim Biophys Acta 1848(2): 581-592.

34. Wijnands KAP, Castermans TMR, Hommen MPJ, Meesters DM, Poeze M (2015) Arginine and Citrulline and the Immune Response in Sepsis. Nutrients 7(3): 1426-1463.

35. Bechtel TJ, Weerapana E (2017) From structure to redox: the diverse functional roles of disulfides and implications in disease. Proteomics $17(6)$.

36. Martin L, van Meegern A, Doemming S, Schuerholz T Antimicrobial peptides in human sepsis. Front Immunol 6:404.

37. Wilmes M, Cammue BPA, Sahl H-G, Thevissen K (2011) Antibiotic activities of host defense peptides: more to it than lipid bilayer perturbation. Nat Prod Rep 28(8): 1350-1358.

38. Fornili SL, Pizzi R, Rebeccani D (2010) conformational analysis of a synthetic antimicrobial peptide in water and membrane-mimicking solvents: a molecular dynamics simulation study. International Journal of Peptide Research and Therapeutics 16(4): 223-231.

39. Navas D, Caillon J, Gras-Le Guen C, Jacqueline C, Kergueris M, et al. (2004) Comparison of in vivo intrinsic activity of cefepime and imipenem in a Pseudomonas aeruginosa rabbit endocarditis model: effect of combination with tobramycin simulating human serum pharmacokinetics. Journal of Antimicrobial Chemotherapy 54(4): 767771.

40. Tavanti A, Maisetta G, Del Gaudio G, Petruzzelli R, Sanguinetti M, et al. (2011) Fungicidal activity of the human peptide hepcidin 20 alone or in combination with other antifungals against Candida glabrata isolates. Peptides 32(12): 2484-2487.

41. Lum KY, Tay ST, Le CF, Lee VS, Sabri NH, et al. (2015) Activity of novel synthetic peptides against Candida albicans. Sci Rep 5: 9657.

42. Matejuk A, Leng Q, Begum MD, Woodle MC, Scaria P, et al. (2010) Peptide-based antifungal therapies against emerging infections. Drugs Future 35(3): 197.

43. Lupetti A, Brouwer CP, Bogaards SJ, Welling MM, de Heer E, et al. (2007) human lactoferrin-derived peptide's antifungal activities against disseminated candida albicans infection. J Infect Dis 196(9): 1416-1424

44. Lloyd-Williams P, Albericio F, Giralt E (1997) In: Lloyd-Williams P, Albericio F, Giralt E (Eds.), Chemical Approaches to the Synthesis of Peptides and Proteins. CRC Press, University of Barcelona, Barcelona, Spain.

45. Kamysz W, Okrój M, Łempicka E, Ossowski T, Łukasiak J (2004) Fast and efficient purification of synthetic peptides by solid-phase extraction. Acta Chromat 14: 180-186.

46. Cuenca-Estrella M, Lee-Yang W, Ciblak MA, Arthington-Skaggs BA Mellado E, et al. (2002) Comparative evaluation of NCCLS M27-A and EUCAST broth microdilution procedures for antifungal susceptibility testing of candida species. Antimicrob Agents Chemother 46(11): 3644 3647.

47. Cudic M, Condie BA, Weiner DJ, Lysenko ES, Xiang ZQ, et al. (2002) Development of novel antibacterial peptides that kill resistant isolates. Peptides 23(12): 2071-2083.

48. Cudic M, Lockatell CV, Johnson DE, Otvos L (2003) In vitro and in vivo activity of a designed antibacterial peptide analog against uropathogens. Peptides 24(6): 807-820

49. William F, Walkenhorst J, Wolfgang Klein, Phuong V, William C (2013) pH dependence of microbe sterilization by cationic antimicrobial peptides. Antimicrob Agents and Chemother 57(7): 3312-3320.

50. Amsterdam D (1996) Susceptibility testing of antimicrobials in liquid media. In: Lorian V (Ed.), Susceptibility testing of antimicrobials in liquid media. ( $4^{\text {th }}$ edn), In Antibiotics in Laboratory Medicine, Williams \& Wilkins, Baltimore, MD, US, pp. 52-111. 
51. Lupetti A, Paulusma-Annema A, Welling MM, Senesi S, van Dissel JT, et al. (2000) Candidacidal activities of human lactoferrin peptides derived from the N terminus. Antimicrob Agents Chemother 44(12): 3257-3263.

52. Lupetti A, Paulusma-Annema A, Senesi S, Campa M, van Dissel JT, et al. (2002) Internal thiols and reactive oxygen species in candidacidal activity exerted by an $\mathrm{N}$-terminal peptide of human lactoferrin. Antimicrob Agents Chemother 46(6): 1634-1639.

53. Lupetti A, Brouwer CP, Dogterom-Ballering H, Senesi S, Campa M, et al. (2004) Release of calcium from intracellular stores and subsequent uptake by mitochondria are essential for the candidacidal activity of a $\mathrm{N}$-terminal peptide of human lactoferrin. J Antimicrob Chemother 54(3): 603-608.

54. Nekhotiaeva N, Elmquist A, Rajarao GK, Hällbrink M, Langel U, et al (2003) Cell entry and antimicrobial properties of eukaryotic cellpenetrating peptides. FASEB J 18(2): 394-396.

55. Nguyen LT, Leonie de B, Sebastian AJZ, Hans JV (2011) Investigating the cationic side chains of the antimicrobial peptide tritrpticin: Hydrogen bonding properties govern its membrane-disruptive activities. Biochimica et Biophysica Acta 1808(9): 2297-2303.

56. Haug BE, Svendsen JS (2001) The role of tryptophan in the antibacterial activity of a 15-residue bovine lactoferricin peptide. J Peptide Sci 7(4): 190-196.

57. Liu Y, Han F, Xie Y, Wang Y (2011) Comparative antimicrobial activity and mechanism of action of bovine lactoferricin-derived synthetic peptides. Biometals 24(6): 1069-1078.

58. Nguyen LT, Chau JK, Perry NA, de Boer L, Zaat SAJ, Vogel HJ (2010) Serum stabilities of short tryptophan- and arginine-rich antimicrobial peptide analogs. PLoS ONE 5(9): e12684.

59. Chan DI, Prenner EJ, Vogel HJ (2006) Tryptophan-and arginine-rich antimicrobial peptides: structures and mechanisms of action. Biochim Biophys Acta 1758(9): 1184-1202.

60. Nibbering PH, Ravensbergen E, Welling MM, van Berkel LA, van Berkel $\mathrm{PH}$, et al. (2001) Human lactoferrin and peptides derived from its $n$ terminus are highly effective against infections with antibiotic-resistant bacteria. Infect Immun 69(3): 1469-1476.

61. Alfred RL, Shagaghi NM, Palombo EA, Mrinal Bhave (2013) Tryptophanrich antimicrobial peptides: properties and applications. Microbial pathogens and strategies for combating them: science, technology and education, Spain pp. 1395-1405.
62. Mojsoska B, Jenssen H (2015) Peptides and peptidomimetics for antimicrobial drug design. Pharmaceuticals 8(3): 366-415.

63. Haag AF, Kerscher B, Dall'Angelo S, Sani M, Longhi R, et al. (2012) Role of cysteine residues and disulfide bonds in the activity of a legume root nodule-specific, cysteine-rich peptide. J Biol Chem 287(14): 1079110798.

64. Mac Callum DM, Desbois AP, Coote PI (2013) Enhanced efficacy of synergistic combinations of antimicrobial peptides with caspofungin versus Candida albicans in insect and murine models of systemic infection. Eur J Clin Microbiol Infect Dis 32(8): 1055-1062.

65. Scott MG, Dullaghan E, Mookherjee N, Glavas N, Waldbrook M (2007) An anti-infective peptide that selectively modulates the innate immune response. Nat Biotechnol 25(4): 465-472.

66. Li RF, Lu YL, Lu YB, Zhang HR, Huang L, et al. (2015) Antiproliferative effect and characterization of a novel antifungal peptide derived from human Chromogranin A. Exp Ther Med 10(6): 2289-2294.

67. Scorzoni L, de Paula ESAC, Marcos CM, Assato PA, de Melo WC, et al. (2017) Antifungal therapy: new advances in the understanding and treatment of mycosis. Front Microbiol 8: 36.

68. Fernandes KE, Carter DA (2017) The Antifungal activity of lactoferrin and its derived peptides: mechanisms of action and synergy with drugs against fungal pathogens. Front Microbiol 8: 2 .

69. Morici P, Florio W, Rizzato C, Ghelardi E, Tavanti A, et al. (2017) Synergistic activity of synthetic $\mathrm{N}$-terminal peptide of human lactoferrin in combination with various antibiotics against carbapenem-resistant Klebsiella pneumoniae strains. Eur J Clin Microbiol Infect Dis 36(10): 1739-1748.

70. Stallmann, HP, Faber C, Bronckers AL, Blieck-Hogervorst JM, Brouwer CP, et al. (2005) Histatin and lactoferrin derived peptides: antimicrobial properties and effects on mammalian cells. Peptides 26(12): 2355-2359.

71. Arias M, McDonald LJ, Haney EF, Nazmi K, Bolscher JG, et al. (2014) Bovine and human lactoferricin peptides!: chimeras and new cyclic analogs. Biometals 27(5): 935-948.

72. Wulferink M, Brouwer CP, Astrid MC, Sluiter-van Dijk, Nicole NA, et al. (2005) The Peptide hLF(1-11) as Broad Spectrum Antmicrobial Prophylaxis in HSCT Patients. Blood 106(11): 3241.

\begin{tabular}{|c|c|c|}
\hline CJMI & 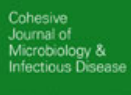 & $\begin{array}{c}\text { Cohesive Journal of Microbiology \& Infectious Disease } \\
\text { Benefits of Publishing with us }\end{array}$ \\
\hline & & $\begin{array}{l}\text { - High-level peer review and editorial services } \\
\text { - Freely accessible online immediately upon publication } \\
\text { - Authors retain the copyright to their work } \\
\text { - Licensing it under a Creative Commons license } \\
\text { - Visibility through different online platforms }\end{array}$ \\
\hline
\end{tabular}

